\title{
Active tectonics and earthquake destructions in caves of northern and central Switzerland
}

\author{
Arnfried Becker ${ }^{1}$, Philipp Häuselmann ${ }^{2 *}$, Jost Eikenberg ${ }^{3}$, and Eric Gilli ${ }^{4}$
}

\begin{abstract}
:
Becker A., Häuselmann Ph., Eikenberg J. and Gilli E. 2011. Active tectonics and earthquake destructions in caves of northern and central Switzerland. International Journal of Speleology, 41(1), 35-49. Tampa, FL (USA). ISSN 0392-6672.

http://dx.doi.org/10.5038/1827-806X.41.1.5

The present publication focuses on the study of caves in northern and central Switzerland in order to detect and date historical earthquakes and active tectonic displacements by investigations of broken and resealed or displaced speleothems datable by U/Th and ${ }^{14} \mathrm{C}$. While it can be shown that these methods are potentially suitable, the ages obtained are often beyond the range of historically recorded earthquakes, and it cannot be proved that the observed and dated events are related to a seismic event. Particularly this is true for the caves in central Switzerland, where most ages in the Melchsee-Frutt region were beyond the limits of the U/Th method, or of late Pleistocene age in the Siebenhengste-Hohgant region. A direct comparison with known historical (or prehistoric) earthquakes was not possible. In contrast to central Switzerland, the results in the Basle region of northern Switzerland indicates cave and speleothem damages in one cave within the epicentral area of the 1356 Basle earthquake. ${ }^{14} \mathrm{C}$ datings allowed to directly relate the speleothem damages to this M 6.9 earthquake. Further dating results from caves in northern Switzerland on speleothems and organic material in cave deposits supplied ages which indicate older events not related to the historical Basle earthquake. The detection of active fault displacements and prehistoric strong earthquakes can only be achieved by a very careful deciphering of the palaeo-environmental records and many more age determinations which allow to separate active tectonic displacements and seismic events from other events not related to tectonics, i.e. glaciations, creep of sediments, catastrophic floods etc.
\end{abstract}

Keywords: active tectonics; seismic events; 1356 Basle earthquake; caves; speleothem dating; Switzerland

Received 7 January 2011; Revised 17 February 2011; Accepted 9 June 2011

\section{INTRODUCTION}

The surface expressions of active tectonics and strong earthquakes are frequently obliterated due to natural surface degradation and human activities, e.g. urbanisation, agriculture, clearing of the landscape, drainage of marshes, etc. All these shortcomings for active tectonics and paleoseismological research at the Earth's surface are insignificant, or at least significantly reduced, in most so-called inactive caves which show negligible ongoing corrosive or erosive enlargement. In such caves, sediment deformation features, faults and fractures are well protected due to almost non-existing weathering processes and can therefore be preserved for hundreds of thousands of years (Kagan et al., 2005) even in soft sediments (Lignier \& Desmet, 2002).

\footnotetext{
${ }^{1}$ Rheinstr. 32, 76344 Eggenstein-Leopoldshafen, Germany (arnfried.becker@kabelbw.de)

2* Swiss Institute for Speleology and karst studies, c.p. 818,
2301 La Chaux-de-Fonds (praezis@speleo.ch)
}

${ }^{3}$ Paul-Scherrer-Institut, 5232 Villingen, Switzerland (jost. eikenberg@psi.ch)

${ }^{4}$ Université de Paris 8, 2 rue de la Liberté, 93526 Saint-Denis Cedex, France (e.gilli@wanadoo.fr)
In this respect, most valuable for research are recently discovered caves or cave sections, because an "anthropogenic impact" can largely be excluded. Particularly in the karstified areas of the Swiss Alps, more than $70 \%$ of the caves have been discovered within the last 35 years. In the Melchsee-Frutt region, for instance, the total length of all known caves was $0.8 \mathrm{~km}$ in 1976 compared with $49 \mathrm{~km}$ in 2004 (Weber, 2004). This circumstance strongly enhances the opportunity to discover neotectonic and paleoseismic deformation features in such caves.

The first systematic investigations of neotectonic deformation and earthquake damage in Swiss caves were conducted in the Siebenhengste-Hohgant system by Jeannin $(1989,1990)$ and in the Basle region by Lemeille et al. (1999), mainly based on the pioneering work by Gilli (1986) and Forti \& Postpischl (1980, 1984) in France and Italy. Although the present seismicity in these two regions of Switzerland is moderate, two strong earthquakes are reported nearby in the historical earthquake catalogue for the last 1000 years (Fig. 1), e.g. the September $18^{\text {th }}, 1601$, $\mathrm{M}_{\mathrm{w}} 6.2$ Unterwalden earthquake near Lake Lucerne, and the strongest recorded earthquake in Europe north of the Alps, the October $18^{\text {th }}, 1356, M_{w} 6.9$ Basle 

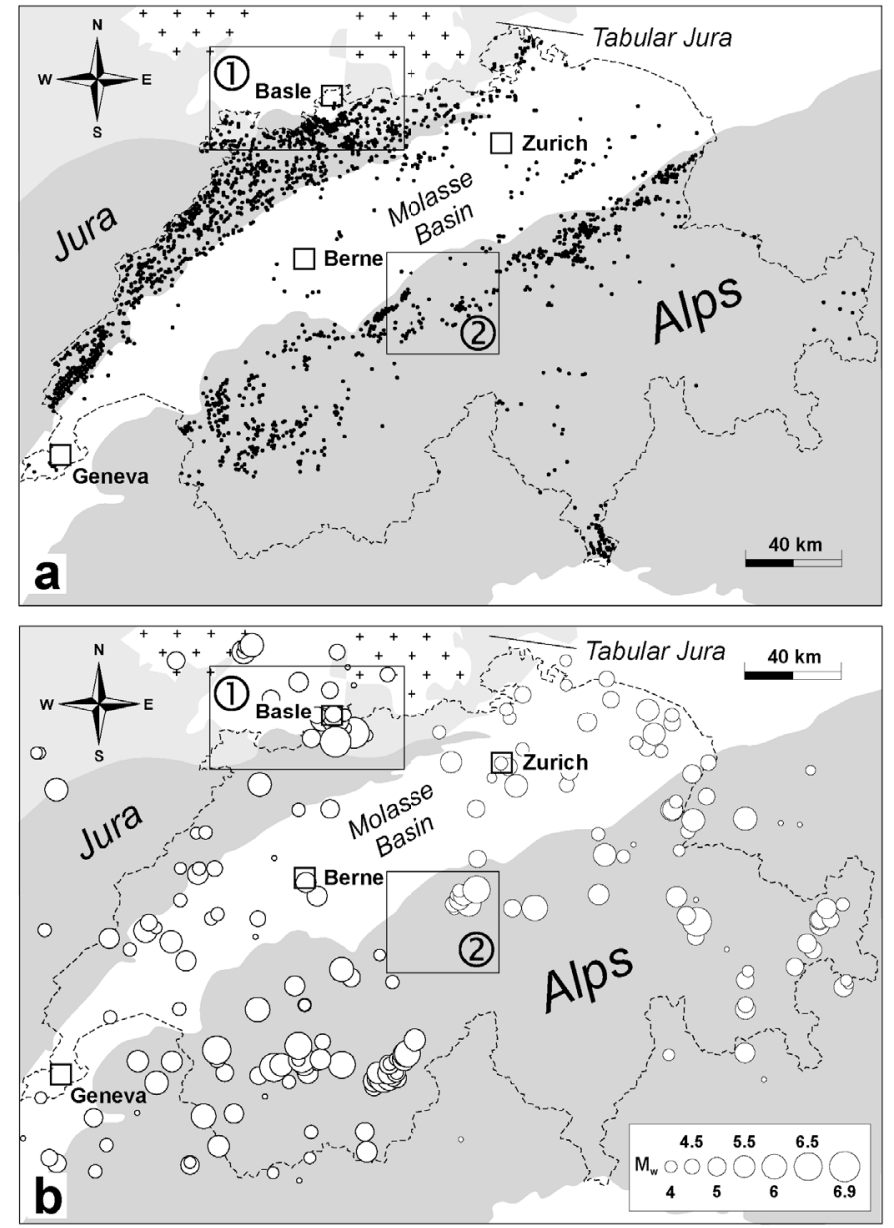

Fig. 1. a) Distribution of cave entrances in Switzerland [black dots]. b) epicentres of larger earthquakes [white circles] for the past 1000 years. The insets show the investigated areas, 1: Jura Mountains around Basle, 2: Melchsee-Frutt and Siebenhengste.

earthquake at the south-eastern termination of the Upper Rhine Graben (Fäh et al., 2003; 2009, MayerRosa \& Cadiot, 1979; Mayer-Rosa \& Schwarz-Zanetti, 2004; Schwarz-Zanetti et al., 2003). In addition, fault scarps are described in the Basle region (Ferry et al., 2005). They are the surface expressions of co-seismic displacements. In the following the results from 13 caves investigated for traces of damage in close and far distances $(\leq 50 \mathrm{~km})$ of the two strongest historical earthquakes in central and northern Switzerland (Fig. 1) and a discussion of the possible causes for the observed damages will be presented.

\section{DATING METHODS}

For the correlation of co-seismic displacements along fault planes and destructions in caves due to seismic shocks, accurate dating methods are needed. For dating cave deposits, i.e. speleothems and sediments, different methods are available, of which the most common $\mathrm{U} / \mathrm{Th}$ and radiocarbon methods have been used in this study.

\section{U/Th method}

In this investigation, 27 authigenic speleothem samples were analyzed using the ${ }^{230} \mathrm{Th} /{ }^{234} \mathrm{U}$ dating method (Ivanovich \& Harmon, 1992; Eikenberg et al., 2001; Eikenberg, 2002; Tepley et al., 2006). The results of the activity concentrations for ${ }^{238} \mathrm{U},{ }^{234} \mathrm{U}$, ${ }^{230} \mathrm{Th}$ and ${ }^{232} \mathrm{Th}$ (the latter isotope was used for detrital correction) are shown in Table 1 . This table contains also the measured ${ }^{230} \mathrm{Th} /{ }^{234} \mathrm{U}$ and ${ }^{234} \mathrm{U} /{ }^{238} \mathrm{U}$ ratio as well as the corrected ratios after subtraction of the detrital component. The calculated ${ }^{230} \mathrm{Th} /{ }^{234} \mathrm{U}$ ages of the authigenic phases are also presented in this table. The results of an additional eight samples dated with the U/Th method are listed in Table 2 .

\section{Radiocarbon method}

Radiocarbon datings were carried out on dispersed organic micro-remains in clayey silts of the Glitzerstein Cave close to Basle and a stalactite in the Milandre Cave. Altogether 11 samples (Table 3) were taken and prepared for accelerator mass spectrometry (AMS) radiocarbon dating. Samples containing dispersed organic material were first wet sieved before the standard acid-alkali-acid (AAA) pre-treatment whereby, after each step, material was centrifuged. The carbonate samples were only dissolved in acid ( $\mathrm{HCl}$ ), before the $\mathrm{CO}_{2}$ obtained was converted to graphite. The preparation and pretreatment of the samples for radiocarbon dating was carried out at the ${ }^{14} \mathrm{C}$-laboratory of the Department of Geography at the University of Zurich. The AMS with the tandem accelerator of the Institute of Particle Physics at the ETH-Hönggerberg was used for dating. The radiocarbon datings of speleothems from Milandre Cave supplied apparent ages which are not corrected for "dead carbon", i.e. dissolved and re-precipitated carbon from the surrounding limestone.

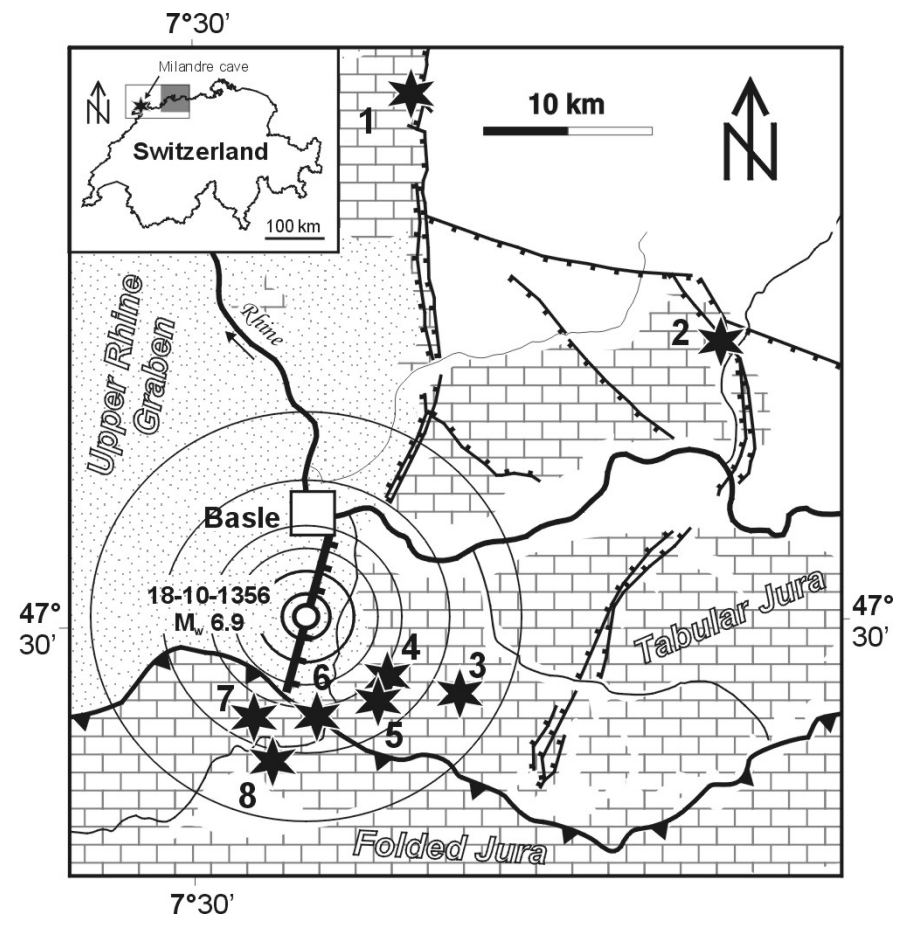

Fig. 2. The study area of the Basle region in northern Switzerland. Investigated caves are: 1 Schallsingen, 2 Erdmann, 3 Lusenberg, 4 Glitzerstein, 5 Kristall, 6 Dieboldslöchli, 7 Fredis Loch, 8 Bättlerloch. Bold jagged line south of Basle indicates the Reinach fault, which is the seismogenic fault of the AD 1356 Basle earthquake. The circles indicate a radius of $1,2,4,8$ and $12 \mathrm{~km}$ around the epicentre. 
Table 1. Results of the U/Th series isotopes in different speleothem samples. Errors are 2sigma.

\begin{tabular}{|c|c|c|c|c|c|c|c|c|c|c|}
\hline \multirow[b]{2}{*}{ Sample } & \multicolumn{4}{|c|}{ concentrations } & \multicolumn{4}{|c|}{ activity ratios } & \multicolumn{2}{|l|}{ ages [ky] } \\
\hline & $\begin{array}{c}{ }^{238} \mathrm{U} \\
{[\mathrm{mBq} / \mathrm{g}]}\end{array}$ & $\begin{array}{c}{ }^{234} \mathrm{U} \\
{[\mathrm{mBq} / \mathrm{g}]}\end{array}$ & $\begin{array}{c}{ }^{232} \mathrm{Th} \\
{[\mathrm{mBq} / \mathrm{g}]}\end{array}$ & $\begin{array}{c}{ }^{230} \mathrm{Th} \\
{[\mathrm{mBq} / \mathrm{g}]}\end{array}$ & $\frac{{ }^{330} T h}{{ }^{2334} U} \frac{)}{\frac{T}{T_{m}}}$ & ${ }^{238} U \frac{{ }^{28} U}{\frac{1}{J_{m}}}$ & 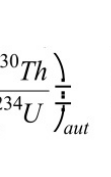 & 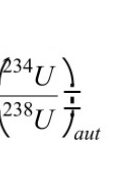 & $\frac{{ }^{230} T h}{\left({ }^{234} U\right.} \frac{1}{\frac{1}{T_{\text {age }}}}$ & remarks \\
\hline \multicolumn{11}{|l|}{ Bettenhöhle-Boniloch } \\
\hline MP34/56-1 & 0.95 & 1.36 & 4.62 & 5.54 & 4.07 & 1.43 & & & & $\begin{array}{l}\text { serious detritus } \\
\text { contamination }\end{array}$ \\
\hline MP34/56-2 & 9.21 & 10.14 & 0.10 & 25.32 & 2.49 & 1.10 & 2.51 & 1.10 & $>250$ & $\begin{array}{l}\text { younger sample ages if } \\
\text { inherited Th }\end{array}$ \\
\hline MP34/56-4 & 33.82 & 35.01 & 0.04 & 30.36 & 0.87 & 1.04 & 0.87 & 1.04 & $>250$ & \\
\hline MP34/56-5 & 9.43 & 13.02 & 0.09 & 21.98 & 1.69 & 1.38 & 1.69 & 1.39 & $>250$ & $\begin{array}{l}\text { younger sample ages if } \\
\text { inherited Th }\end{array}$ \\
\hline MP34/56-6/1 & 11.51 & 15.11 & 0.03 & 16.62 & 1.09 & 1.31 & 1.10 & 1.32 & $>250$ & \\
\hline MP34/56-6/2 & 11.50 & 15.69 & 0.06 & 15.96 & 1.02 & 1.36 & 1.02 & 1.37 & $>250$ & 2. Aliquot of sample 6 \\
\hline MP34/56-7/1 & 5.48 & 11.52 & 0.02 & 5.44 & 0.47 & 2.10 & 0.47 & 2.11 & $75 \pm 10$ & $\begin{array}{l}\text { younger sample ages if } \\
\text { inherited Th }\end{array}$ \\
\hline MP34/56-7/2 & 5.48 & 11.72 & 0.04 & 5.76 & 0.49 & 2.13 & 0.49 & 2.14 & $75 \pm 10$ & 2. Aliquot of sample 7 \\
\hline \multicolumn{11}{|l|}{ Schrattenhöhle } \\
\hline MP 14/44-032/041-1 & 3.86 & 7.10 & $<0.01$ & 6.92 & 0.97 & 1.84 & 0.97 & 1.84 & $>250$ & $\begin{array}{l}\text { Massive disequilibrium } \\
\text { between } 2{ }^{234} \mathrm{U} \text { and } \\
\text { therefore }<1 \mathrm{My} \\
\text { there }\end{array}$ \\
\hline MP 14/44-026/109-2 & 0.32 & 1.06 & 0.12 & 1.53 & 1.44 & 3.31 & 1.50 & 4.80 & $>250$ & $\begin{array}{l}\text { However, equilibrium or } \\
\text { transient disequilibrium } \\
\text { between } \\
\text { 230Th and }{ }^{234} \mathrm{U}, \\
\text { therefore }<1 \mathrm{My}\end{array}$ \\
\hline MP 54/2-Base & 2.21 & 3.70 & $<0.01$ & 3.78 & 1.02 & 1.67 & 1.02 & 1.67 & $>250$ & \\
\hline MP 54/2-Top & 1.76 & 3.12 & 0.01 & 3.78 & 1.21 & 1.77 & 1.21 & 1.77 & $>250$ & \\
\hline \multicolumn{11}{|l|}{ Beatushöhle } \\
\hline BB-1 & 13.6 & 19.5 & 0.17 & 2.00 & 0.102 & 1.43 & 0.092 & 1.44 & $10.5 \pm 0.8$ & Highly suitable for dating \\
\hline BB-2 & 9.7 & 13.8 & 0.07 & 1.02 & 0.073 & 1.42 & 0.068 & 1.43 & $7.7 \pm 0.6$ & Highly suitable for dating \\
\hline BB-3 & 7.5 & 10.7 & 0.07 & 0.34 & 0.032 & 1.43 & 0.024 & 1.43 & $2.6 \pm 0.5$ & Highly suitable for dating \\
\hline \multicolumn{11}{|l|}{ Rundwandhöhle } \\
\hline RW-ZG 3 & 37.3 & 40.4 & 0.12 & 43.8 & 1.08 & 1.08 & 1.08 & 1.08 & $>250$ & Ideal secular equilibrium \\
\hline RW-ZG 3, Aliquot 2 & 39.3 & 42 & 1.27 & 43.8 & 1.04 & 1.07 & 1.05 & 1.07 & $>250$ & 2. Aliquot of sample ZG3 \\
\hline \multicolumn{11}{|l|}{ Sieben Hengste } \\
\hline E9.2NT001/1 & 15.00 & 15.31 & 0.02 & 4.62 & 0.30 & 1.02 & 0.30 & 1.02 & $39 \pm 2$ & flowstone \\
\hline E9.2NT002/1 & 10.33 & 11.41 & 0.35 & 8.31 & 0.73 & 1.10 & 0.72 & 1.11 & $138 \pm 12$ & $\begin{array}{l}\text { Stalagmitic base of a } \\
\text { broken column }\end{array}$ \\
\hline E9.2NT002/2 & 10.04 & 9.14 & 0.03 & 6.75 & 0.74 & 0.91 & 0.74 & 0.91 & $145 \pm 12$ & $\begin{array}{l}\text { Stalagmitic base of a } \\
\text { broken column }\end{array}$ \\
\hline E9.2NT002/3 & 15.22 & 13.28 & 0.11 & 10.88 & 0.82 & 0.87 & 0.82 & 0.87 & $185 \pm 15$ & $\begin{array}{l}\text { Stalagmitic base of a } \\
\text { broken column }\end{array}$ \\
\hline E9.2NT003/1 & 21.14 & 25.19 & 0.13 & 5.22 & 0.21 & 1.19 & 0.20 & 1.19 & $25 \pm 2$ & Stalactite \\
\hline E9.2NT003/2 & 10.03 & 9.01 & 0.10 & 5.51 & 0.61 & 0.90 & 0.61 & 0.90 & $102 \pm 10$ & Stalactite \\
\hline E9.2NT004/1 & 18.28 & 21.59 & 0.09 & 4.96 & 0.23 & 1.18 & 0.23 & 1.18 & $28 \pm 2$ & Column \\
\hline E9.2NT004/2 & 8.35 & 7.95 & 0.09 & 2.10 & 0.26 & 0.95 & 0.26 & 0.95 & $32 \pm 2$ & Column \\
\hline
\end{tabular}

Maximum age, inherited ${ }^{230} \mathrm{Th}$ at mineral formation leads to lower ages 
Table 2. Results of the U/Th datings of the samples from Bettenhöhle and Milandre Cave. Errors are 2sigma.

\begin{tabular}{|c|c|c|c|c|c|c|c|c|c|c|c|c|c|c|c|}
\hline Lab.Nr. & Name & $\begin{array}{c}\mathrm{dU} \text { (korr.) } \\
\left(\% \%_{00}\right)\end{array}$ & $\begin{array}{l}\text { Error } \\
\text { (abs.) }\end{array}$ & $\begin{array}{l}238 \mathrm{U} \\
\text { (ug/g) }\end{array}$ & $\begin{array}{l}\text { Error } \\
\text { (abs.) }\end{array}$ & $\begin{array}{l}\text { 232Th } \\
\text { (ng/g) }\end{array}$ & $\begin{array}{l}\text { Error } \\
\text { (abs.) }\end{array}$ & $\begin{array}{l}\text { 230Th } \\
(\mathrm{pg} / \mathrm{g})\end{array}$ & $\begin{array}{l}\text { Error } \\
\text { (abs.) }\end{array}$ & $\begin{array}{l}\text { Age } \\
\text { (corr.) } \\
\text { (ka) }\end{array}$ & $\begin{array}{l}\text { Error } \\
\text { (ka) }\end{array}$ & $\begin{array}{c}\text { Age } \\
\text { (uncorr.) } \\
\text { (ka) }\end{array}$ & $\begin{array}{l}\text { Error } \\
\text { (abs.) }\end{array}$ & $\begin{array}{l}\text { dU(ini.) } \\
\left(\%{ }_{00}\right)\end{array}$ & $\begin{array}{l}\text { Error } \\
\text { (abs.) }\end{array}$ \\
\hline \multicolumn{16}{|l|}{ Milandre } \\
\hline 2409 & ECH-1Top & 152.5 & 5.0 & 0.12709 & 0.00011 & 1.1303 & 0.0089 & 0.438 & 0.026 & 21.7 & 1.5 & & & & \\
\hline 2409.2 & ECH-1Top/a & 126.3 & 14.0 & 0.10485 & 0.00035 & 1.434 & 0.019 & 0.463 & 0.023 & 29.4 & 1.7 & & & & \\
\hline 2410 & ECH-1-Bottom & 159.7 & 7.8 & 0.09638 & 0.00019 & 12.43 & 0.12 & 1.301 & 0.066 & 128 & 12 & & & & \\
\hline 2846 & Mil-020116-06i & 155.2 & 7.9 & 0.05872 & 0.00012 & 37.63 & 0.23 & 0.56 & 0.012 & 60.7 & 1.7 & 77.9 & 2.5 & 184.2 & 9.4 \\
\hline 2845 & Mil-020116-06a & 174.7 & 5.5 & 0.05354 & 0.00011 & 0.9567 & 0.004 & 0.0392 & 0.0016 & 3.8 & 0.16 & 4.24 & 0.18 & 176.6 & 5.5 \\
\hline \multicolumn{16}{|l|}{ Bettenhöhle } \\
\hline 2246 & Bettenhöhle \#1 & 1895.9 & 55.1 & 0.04883 & 0.0003 & 2.766 & 0.024 & 2.778 & 0.033 & & & & & & \\
\hline 2247 & Bettenhöhle \#2 & 1550 & 19.6 & 0.126504 & 0.0004 & 4.657 & 0.021 & 6.095 & 0.051 & & & & & & \\
\hline 2276 & Bettenhöhle \#3 & 1520 & 9.1 & 0.18003 & 0.00036 & 0.9428 & 0.0065 & 8.709 & 0.096 & 379.8 & 30 & & & & \\
\hline
\end{tabular}

\section{THE BASLE REGION}

In the Basle region at the southeastern termination of the Upper Rhine Graben, caves developed mainly in middle Triassic and middle and upper Jurassic limestones. Most of our investigated caves are located near the epicentre of the AD 1356 Basle earthquake in the Tabular und Folded Jura Mountains south and east of Basle (Fig. 2). Two of these caves had already been analysed for possible indications of past strong earthquakes by Lemeille et al. (1999). More distant from the epicentral area, toward the west, north, and northeast, are the caves of Milandre, Schallsingen and Erdmann (Fig. 2).

\section{Dieboldslöchli Cave}

The Dieboldslöchli cave is placed in the northern Folded Jura Mountains, about $11 \mathrm{~km}$ south of Basle $(6$ in Fig. 2), at the northern limb of the Blauen anticline in $35-45^{\circ} \mathrm{N}$ dipping, thickly bedded, strongly fractured Upper Jurassic Rauracian limestones (Bitterli, 1996; Bitterli-Brunner et al., 1984). The cave entrance is about $85 \mathrm{~m}$ above the river Birs at the foot of a steep cliff. This cliff flanks the left wall of the Birs gorge along a NE trend and bends toward an E-W direction in the area of the Dieboldslöchli Cave, following the northern slope of the Blauen anticline (Fig. 3a). The cliffs are unstable. Several blocks embedded in the thick talus at the cliff's foot indicate rock falls and local cliff collapses. The most recent collapse was in 1975 about $400 \mathrm{~m} \mathrm{~W}$ of the cave entrance (BitterliBrunner \& Fischer, 1988).

The cave is $148 \mathrm{~m}$ long and extends in an E-W direction parallel to the westward extension of the cliff (Fig. 3a). The entrance is a large portal which narrows down into a muddy conduit which finally ends in a large, $30 \mathrm{~m}$ long and $7 \mathrm{~m}$ high chamber (Bitterli, 1996). The yellow-brown clayey, silty and sandy sediments are omnipresent and are at least $1 \mathrm{~m}$ thick, as proven by hand drills at four sites in the cave. The large chamber is $20-40 \mathrm{~m}$ below the overlying surface and developed along a fault striking 60/55SE (Fig. 3a). The fault plane is well exposed in the NW part of the end chamber, which is covered by numerous stalagmites (Fig. 4a). Many stalagmites are broken (Fig. 4b) or show growth anomalies with growth axes bending towards the fault plane (Lemeille et al., 1999), i.e. towards the NW.
Some of the stalagmite stumps in the end room of the cave show 2 to $4 \mathrm{~cm}$ high overgrowths on top with growth axes differing by 20 to $25^{\circ}$ from those of the stumps (Lemeille et al., 1999). Because the stalagmites grow on solid rock surfaces, a steepening of the fault-plane caused the growth axes to deviate between the stalagmite stumps and the overgrowths. This steepening probably was not achieved during a single event but could be regarded as the consequence of several short-duration events or a persistent process of fault steepening since the onset of stalagmite formation. The regrowths are

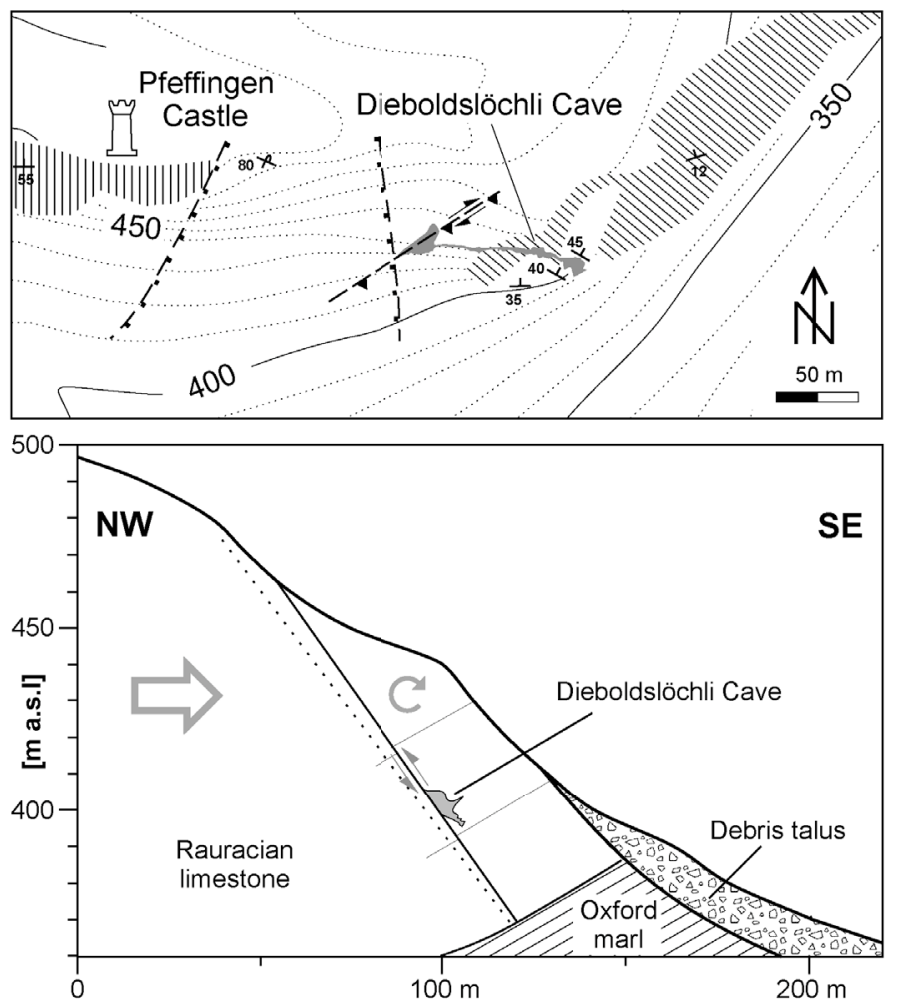

Fig. 3. a) Dieboldslöchli Cave. The map shows the cliff sites (hatched areas), the position of the cave, the thrust fault in the end chamber, bedding orientation and the position of the Pfeffingen Castle. Topographic contours are in meters a.s.l. b) Cross-section including end chamber of Dieboldslöchli cave and surrounding geology. The tectonic block in the west forces the fault-bounded slab including the cave to rotate clockwise, causing steepening of and thrusting along the fault-plane. 

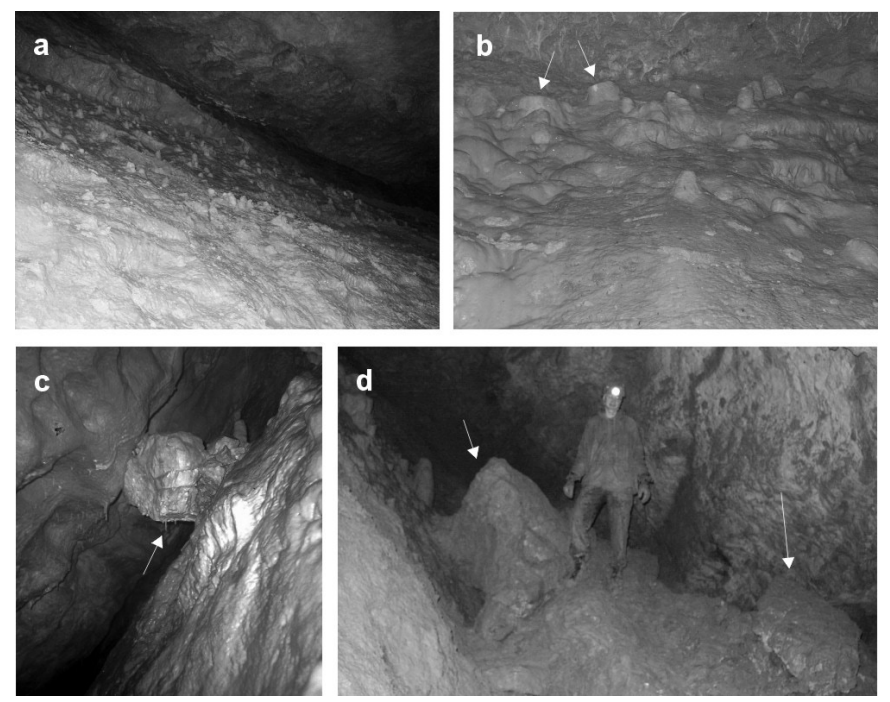

Fig. 4. Photos in Dieboldslöchli cave. (a) shows the fault surface with numerous stalagmites, (b) is a close up, showing several stalagmite stumps (arrows), (c) a locked block on the fault surface which has not moved for a long time, as indicated by vertical soda straws at its base, (d) blocks at the foot of the fracture surface.

slightly offset with respect to the stumps by 2 to $3 \mathrm{~cm}$ in directions between N290E to N320E, indicating a footwall displacement from N110E to N140E (Lemeille et al., 1999). Assuming that the dripping points at the ceiling did not change their positions (e.g., by changes in the hydraulic system), the overgrowth offset indicates oblique dextral reverse displacement along the fault plane (Lemeille et al., 1999).

Radiocarbon age determinations on the oldest layers of four overgrowths point to an onset of regrowth between $1050 \mathrm{AD}$ and $1400 \mathrm{AD}$ (Lemeille et al., 1999). Thus, the last event causing the fracturing of several stalagmites in Dieboldslöchli cave could be most likely related to the AD 1356 Basle earthquake with its seismogenic fault only $3 \mathrm{~km} \mathrm{NW}$ of the cave (Fäh et al., 2009; Ferry et al., 2005) (Fig. 2). This earthquake had a strong impact on several cliffs in the region as indicated by many fallen blocks (Becker \& Davenport, 2003). The damage to Pfeffingen Castle (Fäh et al., 2009) only $200 \mathrm{~m}$ west of the cave (Fig. 3a) shows that the area was hit severely by the earthquake. The fault exposed in the large cave chamber strikes NE-SW and is thus parallel to the northeasterly cliff trend (Fig. 3). The dip of the fault plane is steeper than the slope of the land surface and the $40^{\circ} \mathrm{N}$ dip of the bedding (Fig. $3 \mathrm{~b})$. This is a relatively stable situation. However, slope movements triggered by the Basle earthquake are the most likely reason for the movements along the preexisting fault plane that damaged the speleothems. Probably, the speleothems were not sheared off directly by fault movements. They were either directly broken by seismic shaking or, alternatively, by rock falls in the cave (incasion) triggered by the seismic activity. Loose blocks are still locked between cave ceiling and the fault plane (Fig. 4c) and large blocks can be seen at the base of the fault plane on the cave floor (Fig. 4d). Such blocks tumbling down the fault plane surely would have damaged speleothems on their way down.

\section{Bättlerloch Cave}

Bättlerloch cave is located about $5 \mathrm{~km}$ south of the Reinach fault ( 8 in Fig. 2), which is the seismogenic fault of the 1356 Basle earthquake (Ferry et al., 2005; Meghraoui et al., 2001). The cave is sub-horizontal, trends E-W, and has a total length of $1000 \mathrm{~m}$ (Bitterli, 1996). Speleothems are rare and mainly concentrated in the Znüni Hall (Bitterli, 1996; Lemeille et al., 1999). Here blocks due to cave collapse are frequent and partly covered by stalagmites. These speleothems on top of incasion blocks post-date the fall event and, thus, may allow a determination of the minimum age of the event. Two samples were taken by Lemeille et al. (1999) for $\mathrm{U} / \mathrm{Th}$ and radiocarbon dating. Only the latter method supplied reliable results. Dating of the oldest laminations on top of the blocks give ages of 3630 - $3370 \mathrm{BC}$ for the first and $160 \mathrm{BC}-80 \mathrm{AD}$ for the second block (Lemeille et al., 1999). If the accretion on both blocks began immediately after the rock falls, the dating indicates two independent rockfall events clearly not related to the AD 1356 Basle earthquake.

\section{Glitzerstein Cave}

Glitzerstein cave is located in the Tabular Jura Mountains about $4 \mathrm{~km}$ east of the Reinach fault (4 in Fig. 2). It is a $200 \mathrm{~m}$ long horizontal cave with three entrances (Fig. 5) and a very narrow passage about midway along its length (Haller, 1949). Originally the cave was well decorated with speleothems, but due to easy access, most of the flowstone formations have been damaged or destroyed. Incasion is rare, showing only small rockfall blocks in general. Only the largest chamber, the Hexenküche, contains larger blocks (Fig. 5).

Three sediment samples from underneath the largest block at this site were taken for dating using a lightweight rock core drilling rig for penetrating the block and afterwards a downhole soil sampler that could be hammered into the ground (Becker, 2005). The block was $89 \mathrm{~cm}$ thick at the drill hole. The three soil samples were taken between 0-9 cm, 9-29 cm and $29-33 \mathrm{~cm}$ below the block. All three samples consist of light brown silt to clayey silt containing some (macroscopically invisible) dispersed organic material. The results of radiocarbon dating are given in Table 3.

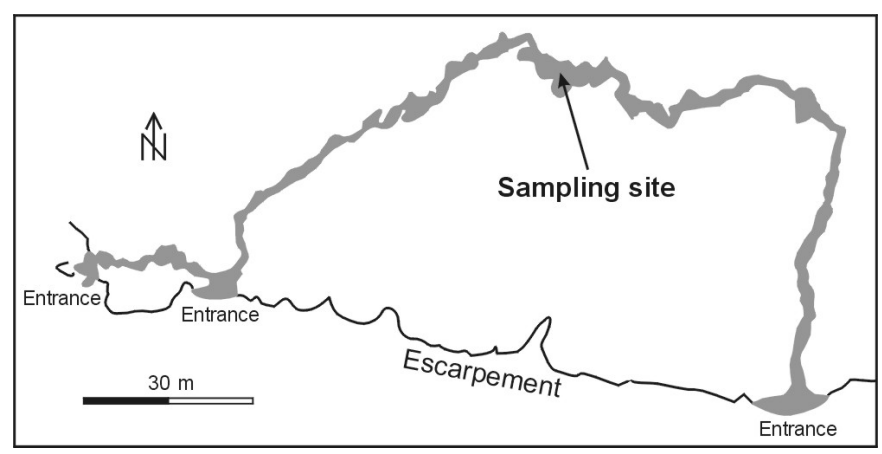

Fig. 5: Map of Glitzerstein Cave and sampling site within the "Hexenküche". 
Table 3. Results of the radiocarbon datings from Glitzerstein and Milandre caves. Errors are 2sigma.

\begin{tabular}{|c|c|c|c|c|c|c|}
\hline Sample & Lab code & $\begin{array}{c}\text { Convent. }{ }^{14} \mathrm{C} \text { age } \\
(\mathrm{BP})\end{array}$ & $\begin{array}{l}\square^{13} \mathrm{C} \\
{[\% 0]} \\
\end{array}$ & Depth $(\mathrm{cm})$ & Material & Remarks \\
\hline GSO-1 & UZ-4837 & $25^{\prime} 480 \pm 370$ & -18.6 & $00-09^{*}$ & \multirow{3}{*}{$\begin{array}{c}\text { Dispersed organic } \\
\text { material }\end{array}$} & \multirow{3}{*}{$\begin{array}{c}{ }^{*} \text { Depth below base } \\
\text { of block }\end{array}$} \\
\hline GSO-2 & UZ-4838 & $33^{\prime} 630 \pm 700$ & -18.1 & $09-29^{*}$ & & \\
\hline GSO-3 & UZ-4839 & $27^{\prime} 460 \pm 360$ & -19.5 & $29-33^{*}$ & & \\
\hline MJU-1.1 & UZ-4906 & $18^{\prime} 410 \pm 130^{*}$ & -2.8 & & \multirow{8}{*}{$\begin{array}{c}\text { Sinter layers from a } \\
\text { stalactite }\end{array}$} & \multirow{3}{*}{$\begin{array}{l}\text { Samples from } \\
\text { stalactite's tips }\end{array}$} \\
\hline MJU-1.2 & UZ-4907 & $8^{\prime} 250 \pm 70^{*}$ & -9.6 & & & \\
\hline MJU-1.3 & UZ-4908 & $26^{\prime} 360 \pm 230^{*}$ & -7.8 & & & \\
\hline MJU-1.4 & UZ-4909 & $41^{\prime} 030 \pm 900^{*}$ & -2.9 & & & \multirow{4}{*}{$\begin{array}{c}\text { *Apparent ages not } \\
\text { corrected for 'dead } \\
\text { carbon'. }\end{array}$} \\
\hline MJU-1.5 & UZ-4910 & $42^{\prime} 960 \pm 1090^{*}$ & -3.0 & & & \\
\hline MJU-1.6 & UZ-4911 & $>44^{\prime} 000^{*}$ & 2.4 & & & \\
\hline MJU-1.7 & UZ-4912 & $>45^{\prime} 000^{*}$ & 1.0 & & & \\
\hline MJU-1.8 & UZ-4913 & $>46^{\prime} 000^{*}$ & -2.0 & & & Oldest sample \\
\hline
\end{tabular}

GSO: Glitzersteinhöhle, MJU: Milandre Cave

The ages of the dated organic material in the sediments fall within the same time period in the Late Pleistocene. The conventional radiocarbon ages lie between 25,500 and 33,600 yr BP with two samples giving very similar ages and standard deviations. Only the sample from 9-29 cm below the block gives a slightly higher age with a standard deviation nearly twice as high as those of the other two samples. Based on these ages the rockfall event could have happened at any time since the deposition of the organic sediments in the Late Pleistocene. If the incasion happened during the AD 1356 Basle earthquake, it is not possible to prove this with the results of radiocarbon dating.

\section{Milandre Cave}

Milandre cave is located north of Porrentruy in the Tabular Jura, close to the margin of the Upper Rhine Graben and about $40 \mathrm{~km}$ west of the epicentre of the Basle earthquake (inset in Fig. 2). The active river cave is $10.5 \mathrm{~km}$ long and highly decorated. Broken speleothems are frequent and seem to record different phases of destruction (Weber, 2004). Some of them are directly related to displacements along fractures with the clearest evidence along a N-S fault system (Weber, 2004, see Fig. 6). However, most of the damage is not related to fault displacement or earthquake shocks, but more likely to floods, sediment collapse and incasion. Most of these events could theoretically be dated, but only a small number of sites has been sampled and investigated. We therefore limit ourselves to the description of three analysed samples from three different sites, named Yt (for Young Tectonics) (Fig. 6: Yt1, Yt 7 and Yt 13).

Site Yt1 is close to the upper entrance of Milandre Cave (Fig. 7). It shows a broken stalactite that was subsequently cemented to the floor of the passage. The goal was to date the cementing flowstone in order to obtain a minimum age for the breakage, as well as

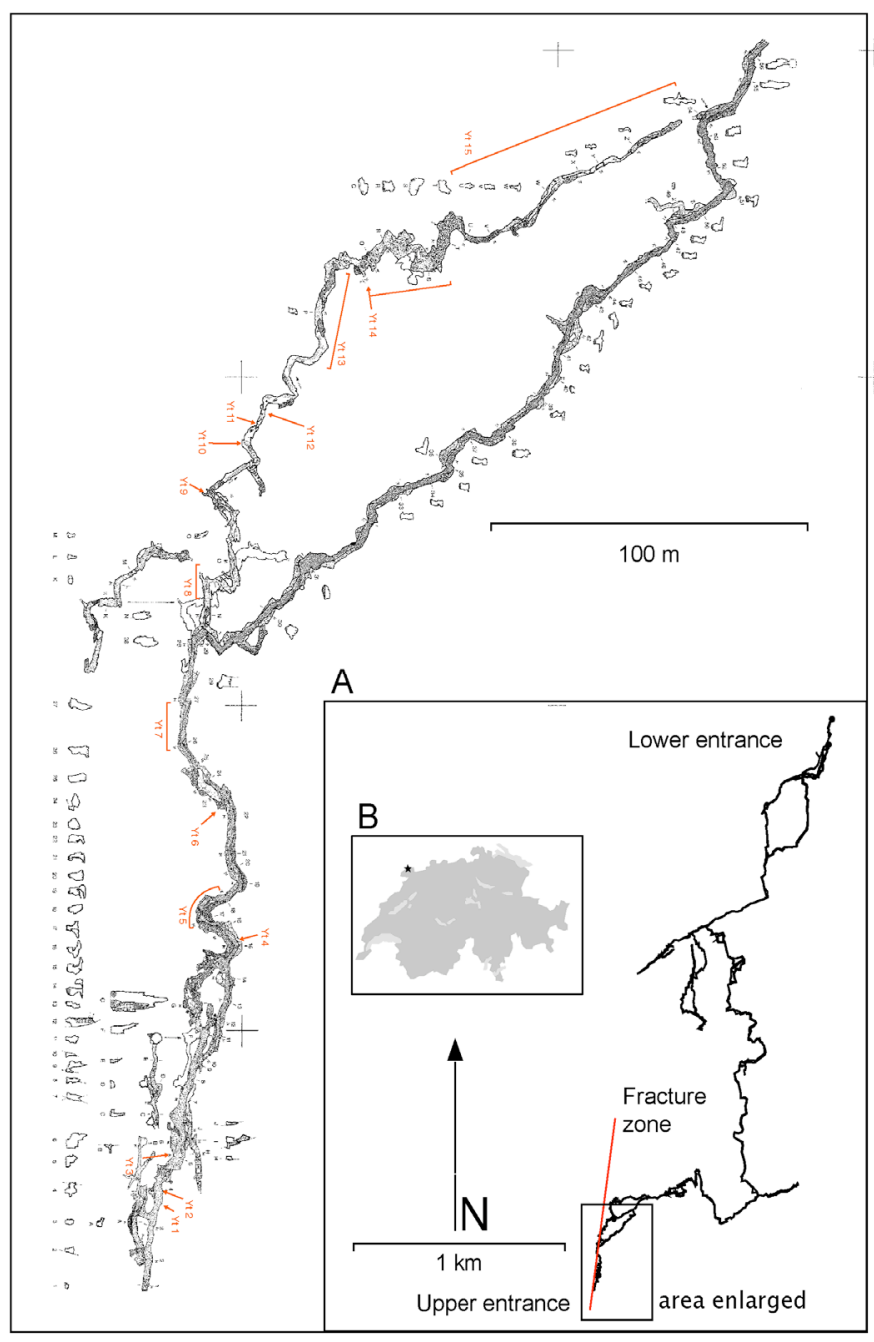

Fig. 6: Location of observation points and sampling sites in the southern part of Milandre cave (compare inset A) in northern Switzerland (inset B). 
the stalactite for an upper age range. The flowstone (sample ECH1, lab number 2409/2410) was dated with the U/Th method (Table 2). The flowstone yields 21 resp. $29 \mathrm{ka}( \pm 1.7 \mathrm{ka})$. The cemented speleothem, which contains some detrital Th, yields 128 ka $( \pm 12 \mathrm{ka})$. The age span between the breaking of the speleothem and the cementing to the floor is therefore approximately $100 \mathrm{ka}$.

Site Yt7 (Fig. 8) contains many broken stalactites near the ceiling of the main passage. Newly formed overgrowths directly overlying the fracture surface are common. The reason for stalactite failure is unknown. Because the sampling site is located in the active main river passage, Weber (2004) hypothesizes that it might have been an exceptionally high flood. This hypothesis is corroborated by thin clayey coatings separating some calcite layers in the sample from location Yt7, which has been sampled for ${ }^{14} \mathrm{C}$-dating (Fig. 8). Following the internal layering of the stalactite, eight subsamples were taken for dating purposes. The results for the carbonate samples of the Milandre Cave were not corrected for the 'dead carbon proportion' (dcp), which would be necessary to correctly determine the ages of the samples. Thus, the results give only 'apparent ages' which are older than the ages of samples from organic-derived carbon directly in exchange with the atmosphere (Table 3).

The apparent ages of the interior (older) parts of the sample are all above $44 \mathrm{ka}$. The dating of the material regrown after the breakoff of the lower part of the stalactite gives an apparent age of $42 \mathrm{ka}$. The subsamples from the two active dripping points at the tips of the stalactite indicate apparent ages of 8.2 and $18.4 \mathrm{ka}$ (Tab. 3), which clearly demonstrates the effect of the "contamination" with old carbon, obviously resulting in very different ${ }^{14} \mathrm{C}$ activities and different apparent ages.

At site Yt 13 (Fig. 9), many displacements are visible. They probably involved a bedding plane rather than a subvertical fault. Overgrowths are visible, and the broken pieces are strewn on the floor. A draperytype stalactite formation (sample 5, lab number 2845/2846) was dated with the U/Th method (Table 2). The drapery was broken by a displacement and later resealed by speleothem growth. The older, broken speleothem is contaminated (high ${ }^{232} \mathrm{Th}$ content), and therefore the age obtained had to be corrected. It yields a corrected age of $60.7 \mathrm{ka}( \pm 1.7$ $\mathrm{ka}$, Table 2). The speleothem cementing the fracture is much cleaner (as can be seen on figure 9), but still a correction has been applied. The corrected age is 3.8 ka $( \pm 0.16 \mathrm{ka})$.

To summarize the results, no proof from dating has yet been found that Milandre Cave may have been affected by the 1356 Basle earthquake. All of the dated events are considerably older. The question remains whether the widespread damage seen in the whole cave could be related to older earthquakes, or whether other reasons should be considered.

In fact, giant floods might be good explanations for most of the widespread damage of speleothems seen in the cave. However, parts of the cave also show damage where floodwaters were unlikely to reach even during

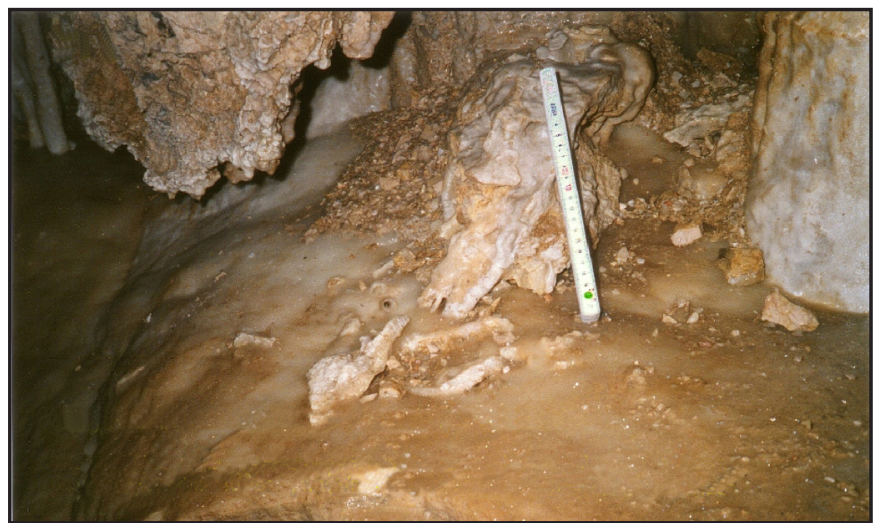

Fig. 7. Drapery at Yt1, Milandre Cave. The location of the Yt sites is indicated on figure 6 .
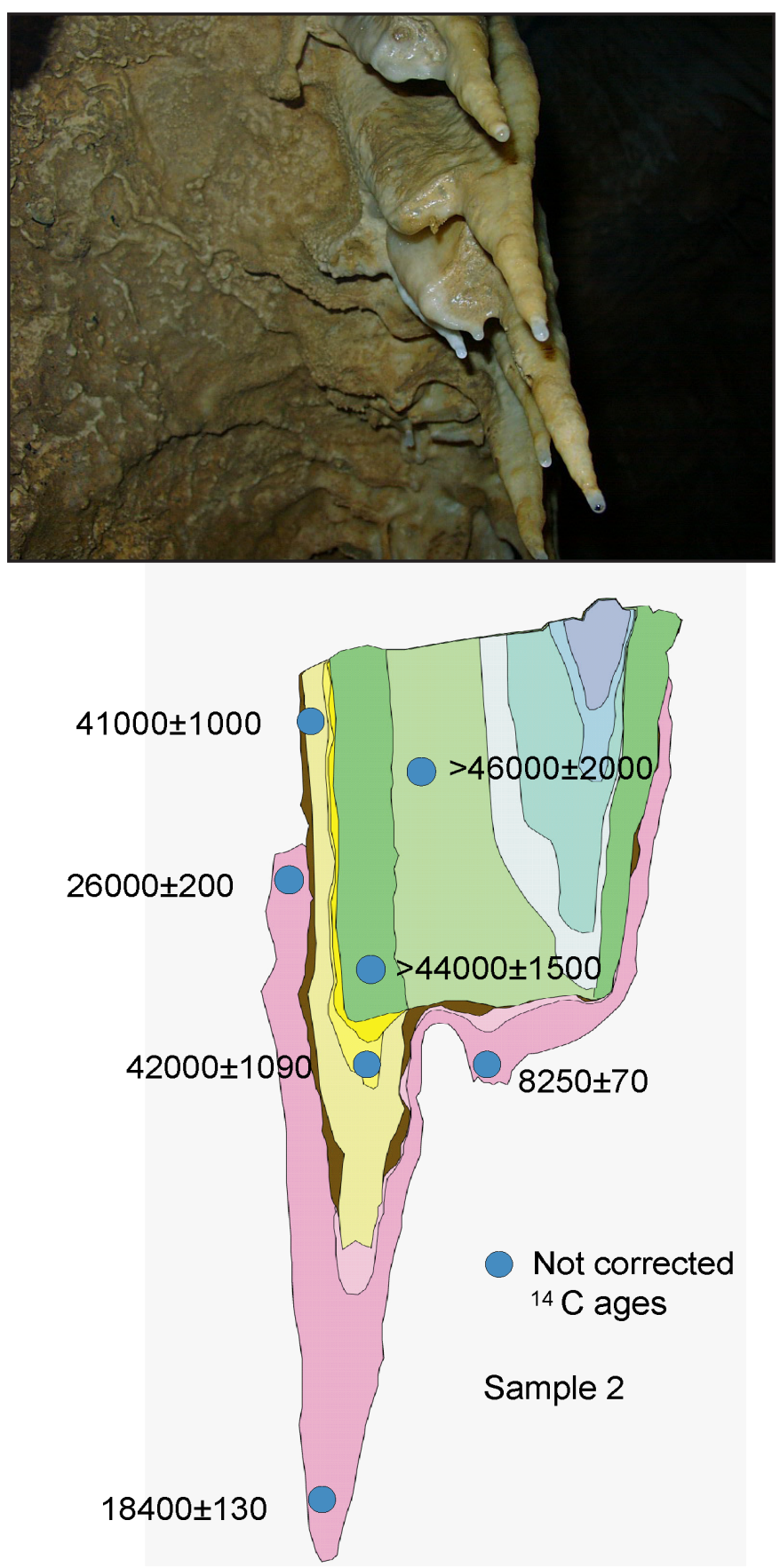

Fig. 8. Photo (a) and sketch (b) of the dissected sample at Yt 7 , Milandre Cave. 


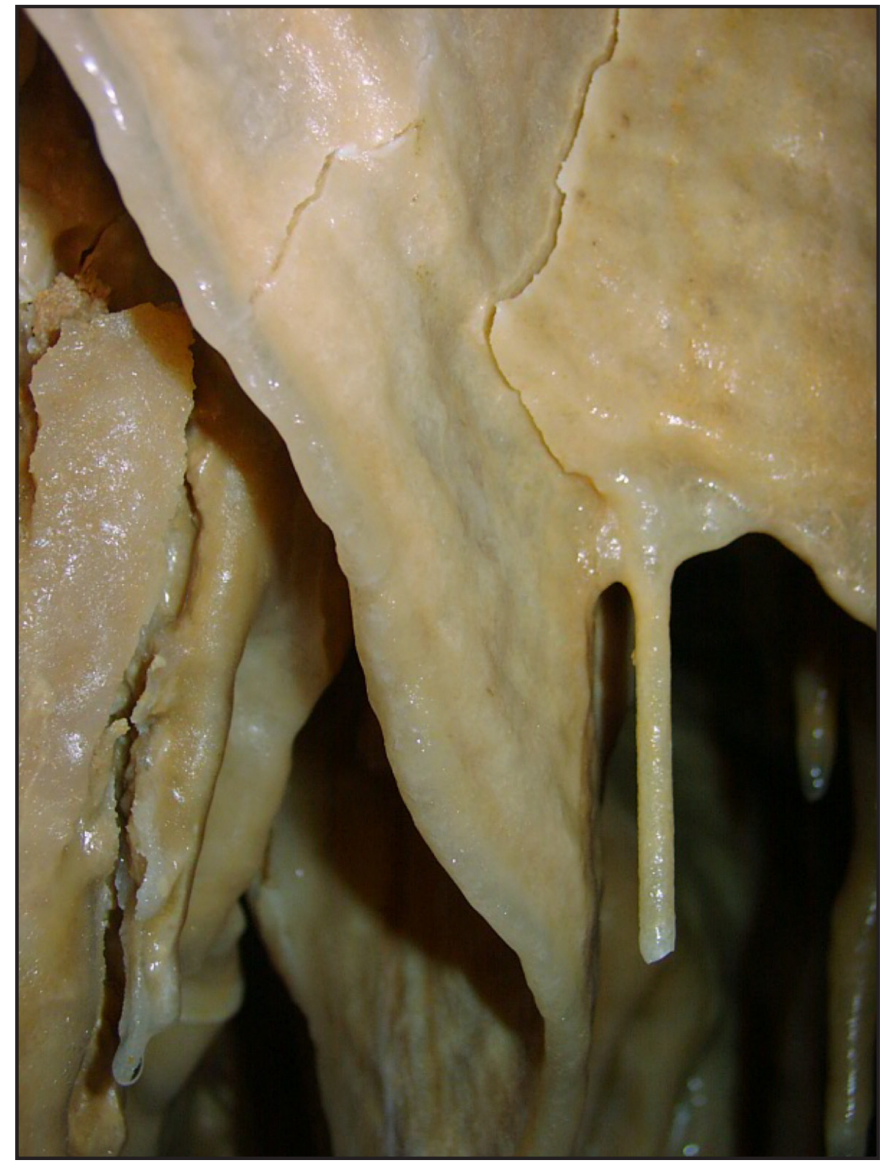

Fig. 9. Drapery at Yt13, Milandre Cave.

very high floods. In addition, in some parts of the cave damage of all kinds of speleothems is omnipresent so that tectonic displacements along faults and beddingplanes is very likely. It is most probable that the damage in the cave is the combination of catastrophic events such as exceptional floods or earthquakes, in addition to long-term tectonic deformations as well as common processes of speleothem damage such as increase of pore pressure behind sinter coatings on the ceiling, undermining of stalagmites, failure of columns under the load of the overburden rock mass, etc. In addition the creep of a former fill in cave passages, e.g. clay deposits or ice, may also be responsible for the damage. More dating coupled with a relative chronology of depositional and erosional events in the cave could help to distinguish the different processes and link stages of speleogenesis with geomorphologic processes at the Earth's surface (Häuselmann et al., 2008).

\section{Other caves in the Basle region}

An additional five caves were examined for possible damage caused by the AD 1356 Basle earthquake: Fredi's Hole (7 in Fig. 2), Lusenberg Cave (3), Kristall Cave (5), Erdmann Cave (2) and Schallsingen Cave (1). With the possible exception of Kristall Cave, evidence for possible damage due to the Basle earthquake could not be found.

Kristall cave is situated close to the summit at the western margin of the Gempen Plateau. Cliff sites immediately west of the cave failed during the AD 1356 Basle earthquake, as can be shown by several radiocarbon dates on rockfall blocks (Becker \& Davenport, 2003). Because of its topographically exposed position (Gilli et al., 1999) in an area which strongly suffered from the AD 1356 Basle earthquake, it is quite possible that the widespread damage seen in the cave could be earthquake triggered, because most of the damage in this cave, which was discovered in 1972, is clearly not recent and thus not related to vandalism or quarry exploitation. No age determinations are available from Kristall cave.

\section{Summary for the Basle region}

For the Dieboldslöchli Cave, damage caused by the Basle earthquake is strongly supported by the data (Lemeille et al., 1999), and for the Kristall Cave it can be regarded as very likely. Both caves are only 3 to $5 \mathrm{~km}$ away from the seismogenic fault in a rather unstable cliff or on top of a mountain close to a deep valley incision. Incasion blocks also occur in other caves in the epicentral area, but their relationship to the Basle earthquake could not be determined, or it could be shown that they are older (Becker, 2005, Lemeille et al., 1999). For all the other caves, independently of their distances from the epicentral region, it appears that the Basle earthquake did not cause any cave damage.

\section{THE REGION OF MELCHSEE-FRUTT}

The area of investigation at the southern end of Melchtal in central Switzerland (Canton of Obwalden) is located on a mountain slope that dips to the north and culminates at Bonistock (2180 m.a.s.1.). Its location is shown in Fig. 10. This region has been selected because it is located close to the Unterwalden earthquake of September, $18^{\text {th }}, 1601$, and because several examples of speleothem damage have been reported (e.g. Gubler \& Trüssel, 1997). In the thesis of Weber (2004) a classical geological study was conducted, focusing on a detailed 3D geological modelling of the region, and on the compilation and analysis of evidence of recent rock displacement visible in caves of this region.

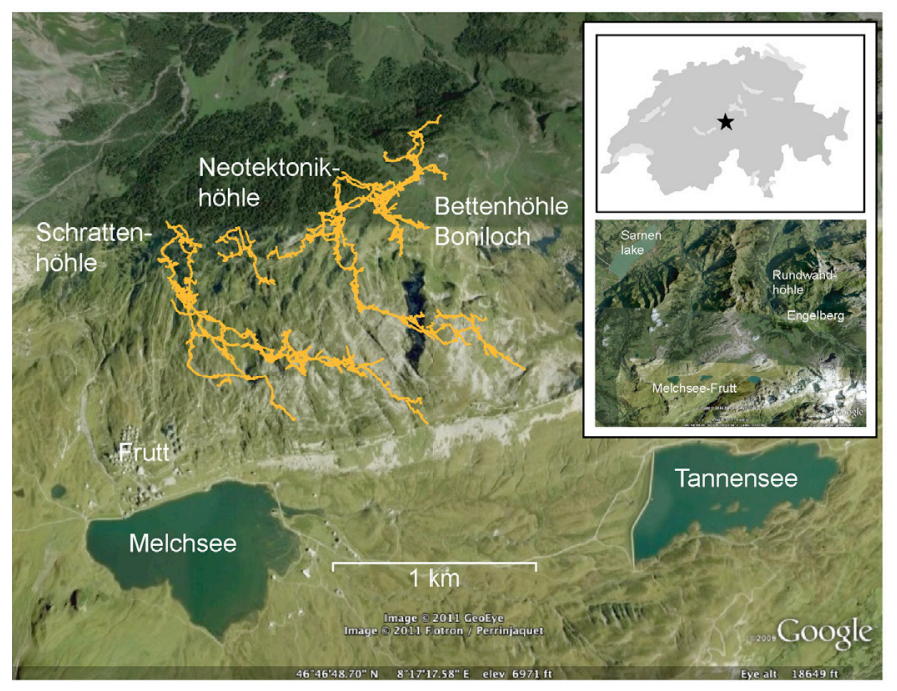

Fig. 10. Insets: Location of the Melchsee-Frutt area in central Switzerland. Main frame: position of the most significant caves of the Melchsee-Frutt (mapped parts in orange colour). 
In addition to the caves of Melchsee-Frutt, Rundwand Cave in the Bannalp karst area (inset Fig. 10) was visited. Rundwand Cave is a fossil phreatic cave that contains traces of tectonic movements. The cave developed along a fault plane that was later reactivated.

\section{Bettenhöhle/Boniloch cave}

The two caves Bettenhöhle and Boniloch were connected after completion of the research project. Therefore, some samples or designations may be written as "Boniloch" or "Bettenhöhle", which are now part of one cave called Bettenhöhle. The localities and their numbers have not changed. The Bettenhöhle cave shows many fractures with neotectonic movements. However, determination of the sense of these movements as well as the amount of displacement is usually impossible. Sample 1 was collected at mapping point $34 / 56$. It is a drapery whose tip broke off and was overgrown by new speleothems. Altogether seven subsamples were taken.

With the exception of the first aliquot, all subsamples (Fig. 11) are characterized by low detritus, i.e. they should be highly suitable for ${ }^{230} \mathrm{Th} /{ }^{234} \mathrm{U}$ dating. However, since the ${ }^{230} \mathrm{Th} /{ }^{234} \mathrm{U}$ ratios are close or above unity, it is likely that this material contains inherited ${ }^{230} \mathrm{Th}$ or additional ${ }^{230} \mathrm{Th}$ from decay of excess ${ }^{234} \mathrm{U}$. This is probable, because the $\left({ }^{234} \mathrm{U} /{ }^{238} \mathrm{U}\right)$ ratios additionally exceed unity. Because the initial $\left({ }^{234} \mathrm{U} /{ }^{238} \mathrm{U}\right)_{\text {aut }}$ ratios are not known, a lower limit of about $250 \mathrm{ky}$ can be estimated for these samples. Only the youngest subsample from this profile (i.e.

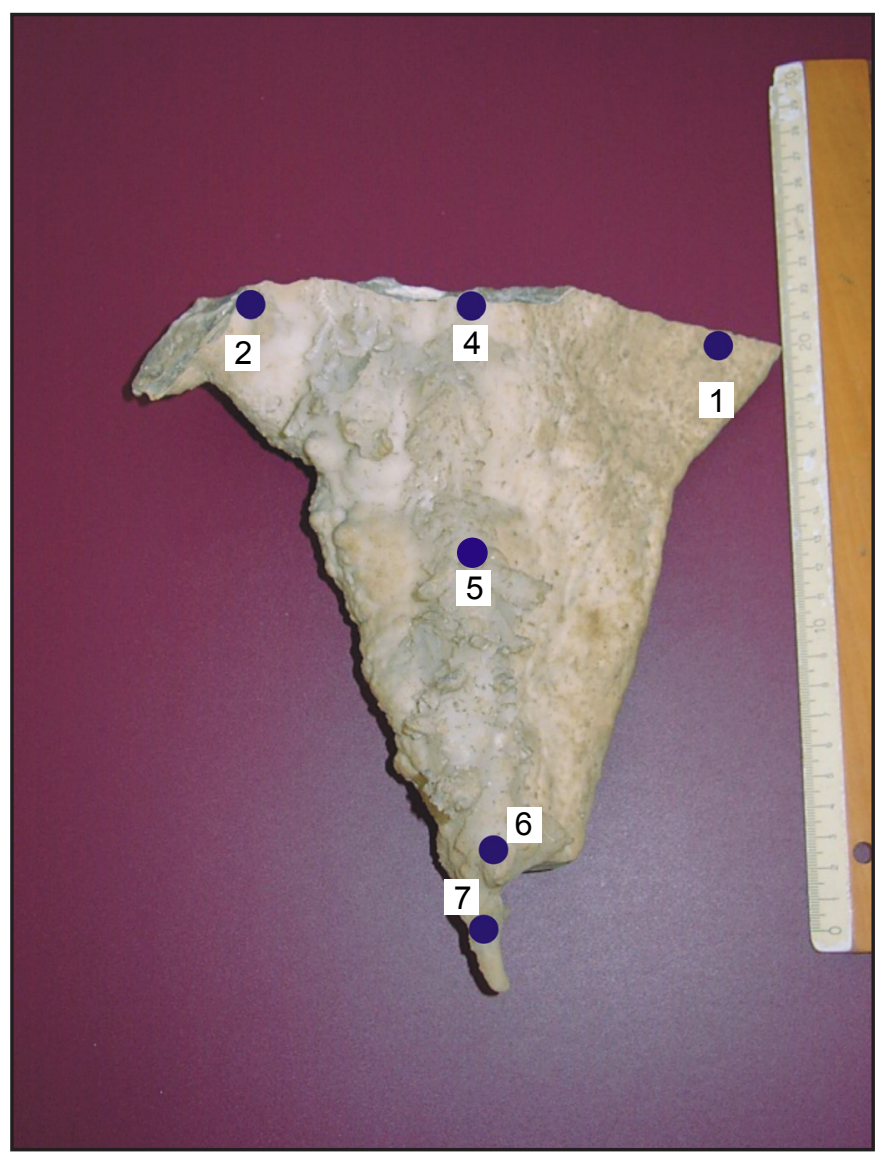

Fig. 11. The dated drapery from the Boniloch (Melchsee-Frutt) with location of the dated sub-samples.

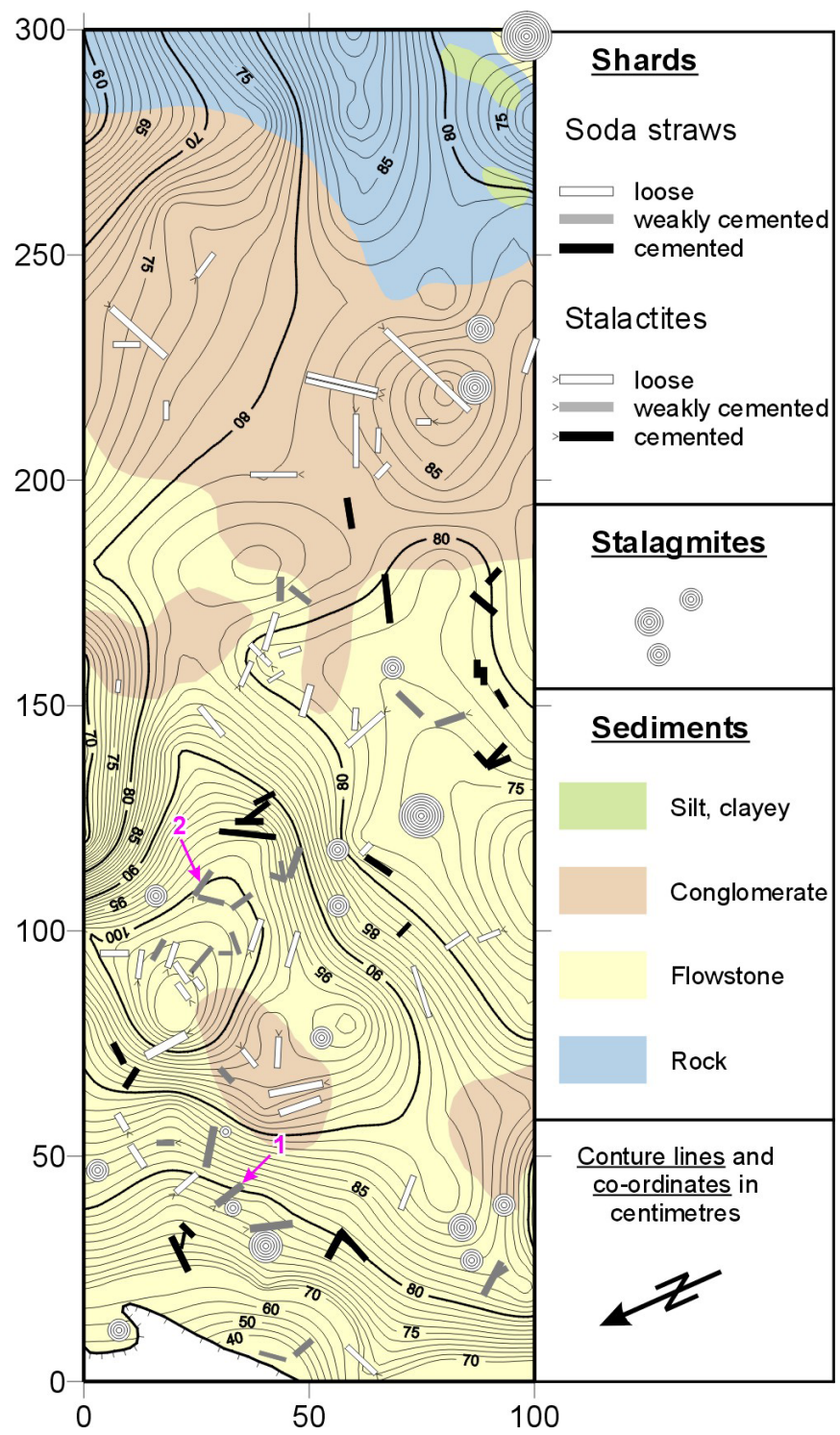

Fig. 12. Map of the field of broken speleothems in Schrattenhöhle (Melchsee-Frutt) with the two dated sub-samples.

subsample MP34/56-7) yields a considerably lower $\left({ }^{230} \mathrm{Th} /{ }^{234} \mathrm{U}\right)_{\text {aut }}$ ratio. Assuming no inherited ${ }^{230} \mathrm{Th}$ upon formation, we dated this last subsample to a maximum age of about $75 \mathrm{ka}$.

Three more samples, in this case soda straws, were collected from Bettenhöhle at the site Sanduhrgang, MP166/68. One soda straw was in place, the other two were collected from the cave floor.

Dating by A. Mangini (University of Heidelberg, Germany) showed that all samples are close to or above the dating limit (Table 2). Therefore, Mangini (written communication) concluded that the samples had a minimum age of $380 \mathrm{ka}$.

\section{Schrattenhöhle}

The Schrattenhöhle at the Oasenlabyrinth site (mapping point 14/44) is highly decorated with concretions. Some stalactites and soda straws have failed, dropped to the floor, and were partially or completely cemented to the ground by flowstone (Fig. 12). Depending on the degree of cementation loose, weakly cemented, or cemented - the broken speleothems allow us to establish a relative chronology of failing events. The flowstone cementing the soda 


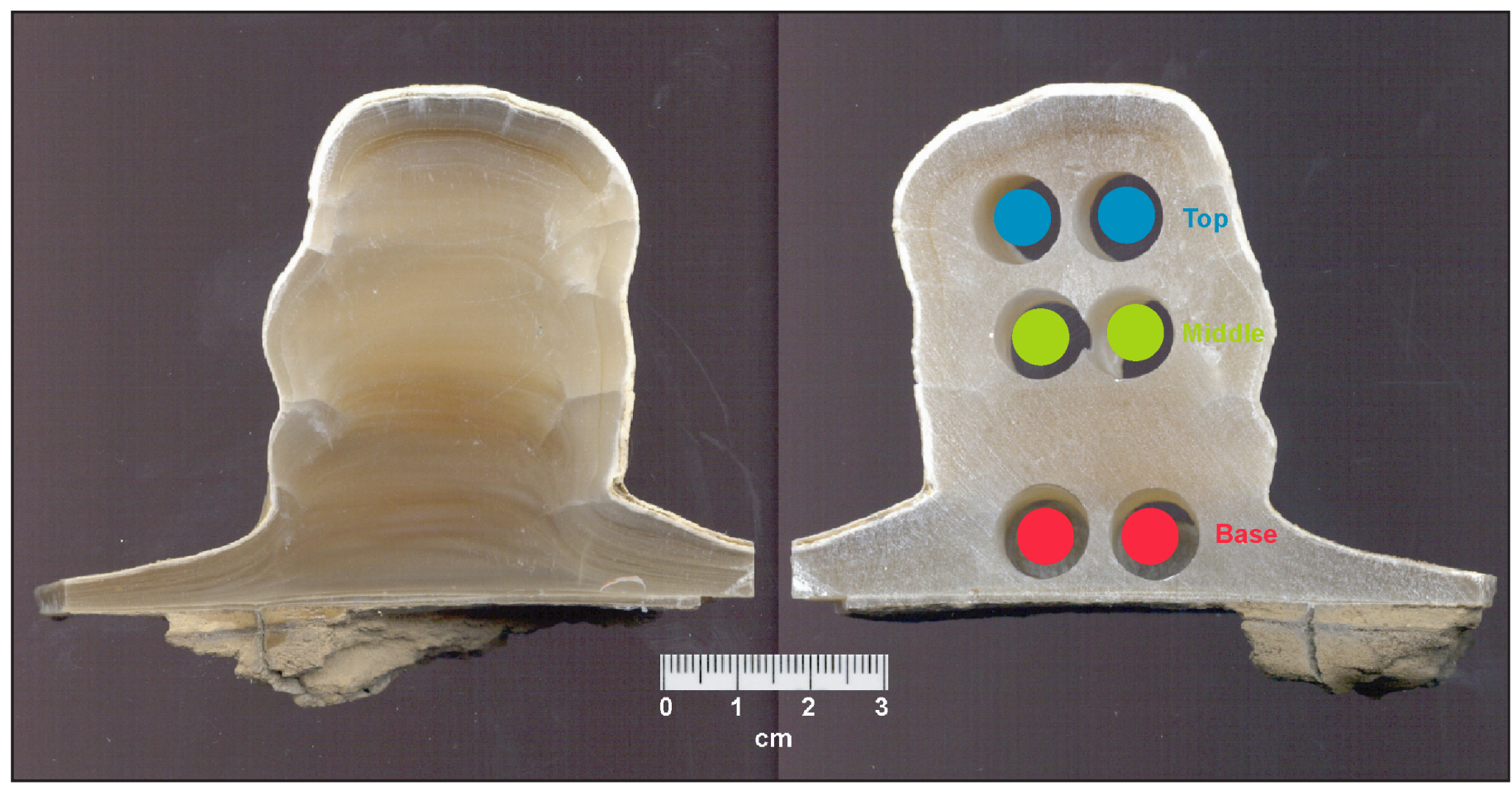

Fig. 13. The stalagmite from measuring point $54 / 2$ in Schrattenhöhle, with position of the sampled points.

straws looks homogeneous and is not ruptured, so we are convinced that it had grown continuously: The degree of cementation is therefore a good estimation of relative age of the soda straw failure. Two of the partially cemented older stalactites were sampled for dating. It was revealed based on ${ }^{230} \mathrm{Th} /{ }^{234} \mathrm{U}$ dating that they could not be dated more precisely than $>250 \mathrm{ka}$ (Table 1) . Also for a nearby small stalagmite collected close to the Oasenlabyrinth at mapping point 54/2 (Fig. 13) an age $>250$ ka was obtained (Table 1).

\section{Rundwand cave}

The sample from Rundwand cave is a very small stalactite that grew on the fault plane which was still active after the cave has been formed. The stalactite is thus younger than the youngest displacements on the fault plane. The sample has a very high U content, which greatly facilitates age dating. Additionally, the detrital content is low. However, the obtained age is above the U/Th limit of $350 \mathrm{ka} .234 / 238 \mathrm{U}$ disequilibrium calculations gave a possible age of about $500 \mathrm{ka}$. Thus, the displacement along the fault plane must be older than $500 \mathrm{ka}$.

\section{Interpretation of the Melchsee-Frutt region}

Based on a $3 \mathrm{D}$ visualisation and an analysis of the geometry of the fault network, the reactivated fractures and the displacement vectors, it can be concluded that most of the observed damages (Fig. 14) and displacements are related to gravitational sliding of the rock mass towards the valley, partly facilitated by the favourable orientation and geometry of preexisting fractures. It is possible that earthquakes accelerated some of these gravitational movements, however, no dating could confirm this hypothesis. The latest ice advance in the heavily glaciated area may also have played a significant role in the observed activation of fault displacements.
The present dating results reveal that all but one sample are beyond the limits of the U/Th method. The fact that most of the dated speleothems are old is no surprise, when one considers the presumed age of the cave (early Pleistocene-Pliocene?). However, in some areas, speleothems are still actively growing. Therefore, there still remains the possibility that more recent earthquakes can be dated. Detrital contamination is not always present and $U$ content is moderate but normal, which means that, technically, dating should also be possible. In order to investigate the area in more detail the possibility of ruptures by earthquakes, very young samples must be sought.

\section{THE SIEBENHENGSTE-HOHGANT REGION}

\section{Siebenhengste-Hohgant system}

With a total length of $154 \mathrm{~km}$, the SiebenhengsteHohgant system is the second longest cave system in Switzerland. It is located north of Lake Thun. From the 1990s on, the genesis of this cave system was investigated in detail (Bitterli \& Jeannin, 1997, Jeannin et al., 2000, Jeannin \& Häuselmann, 2005). A chronology of the karst conduit network development could be established and dated. Conduits have formed successively during the last $4.4 \mathrm{Ma}$ (Häuselmann et al., 2007).

Former studies (Jeannin, 1989, 1990) indicated much evidence of "recent" rock displacements (Fig. 15) and speleothem damage. Three phases of neotectonic displacements along faults and bedding planes in various parts of the Siebenhengste-Hohgant system could be found. They all have an orientation WNWESE and show displacements ranging from 1 to $31 \mathrm{~cm}$. The first compressive deformation is visible mostly on dextral strike-slip faults and can tentatively be related to last stages of Alpine compression and uplift during 


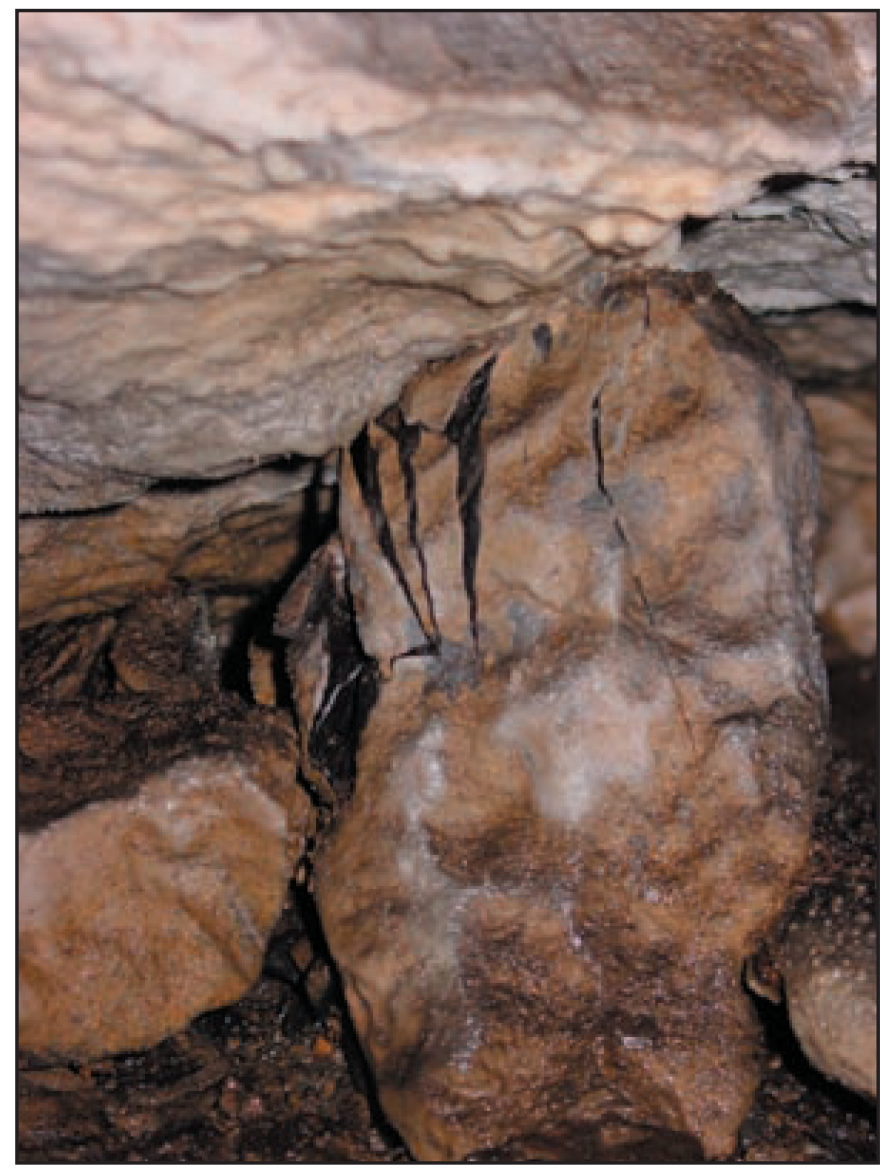

Fig. 14 Pebble fractured by activite bedding plane slip caused by gravitational sliding. Schratten cave, Melchsee-Frutt. The size of the pebble is about $12 \mathrm{~cm}$, movement of the hanging wall from the right to the left.

the Pliocene. The second deformation is extensional and affected mainly bedding planes (Fig. 15). Its cause is unclear, possibly related to glacial unloading. The third (and youngest) phase again affected strike-slip faults. Relative age dating of the cave passages does not reveal the age of the movements that affected the area; therefore, speleothems in a passage that formed along a recently active strike-slip fault with a total displacement of about $20-30 \mathrm{~cm}$ were investigated and dated (Fig. 16).

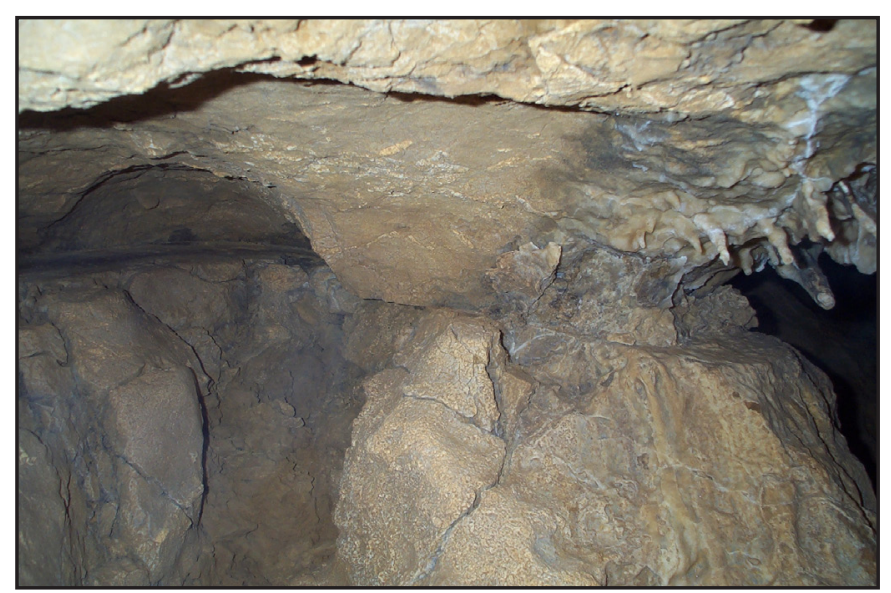

Fig. 15. Young displacement along a bedding plane in the Siebenhengste System. Width of photo about $1.2 \mathrm{~m}$; displacement of top from the right to the left.
None of the damaged speleothems could be expected to have been broken directly by an earthquake (Weber 2004). They seem to have been destroyed by slow displacements along the fault plane, since continuous displacements along at least one speleothem (E9.2NT04) are visible. Earthquakes are caused by discrete ruptures, therefore we consider that these damages are not related to seismic events. Speleothems of different ages have been damaged, making it possible to date the respective displacement steps. They showed almost no detrital contamination, ratios $\left({ }^{230} \mathrm{Th} /{ }^{234} \mathrm{U}\right)_{\text {aut }}<1$ and $\left({ }^{234} \mathrm{U} /{ }^{238} \mathrm{U}\right)_{\text {aut }}$ close to equilibrium. For all four samples meaningful ${ }^{230} \mathrm{Th} /{ }^{234} \mathrm{U}$ ages could be derived (Table 1 ).

Sample E9.2NT01 is a stalactitic cement broken by the last activity of the fault, which shows a displacement of $3 \mathrm{~cm}$. The layer postdating the dextral strike-slip movement gives an age of $32 \pm 2 \mathrm{ka}$.

Sample E9.2NT02 is the stalagmitic base of a column that was twice broken and resealed. The base of this column predates, and the first seal postdates, the first rupture, which was probably due to an extensional movement. Later, a second, possibly strike-slip movement broke off the top of the stalagmite. This fracture also was then resealed. The original column gives an age of $185 \pm 15 \mathrm{ka}$, the first seal yielded $145 \pm 12 \mathrm{ka}$, and the last overgrowth was at $138 \pm 12 \mathrm{ka}$. The first, probably extensional, movement therefore was between 185 and $145 \mathrm{ka}$, the second one between 145 and $138 \mathrm{ka}$.

Sample E9.2NT03 is a stalactite that was broken and had a small regrowth. The original stalactite yielded an age of $102 \pm 10 \mathrm{ka}$, the regrowth $25 \pm 2 \mathrm{ka}$.

Sample E9.2NT04 is a column that was broken and later resealed completely. Here, we see a shift in the drip center that seems to be continuous throughout the newly deposited calcite layers. We therefore can conclude that the dextral strike-slip movement was rather regular. The normal fault became reverse (transpression), and the movement was very slow, because some parts of concretion grew as a column and were not broken by the movement, which had to be consistent while the growth occurred. Dating of the original column yielded an age of $32 \pm$ $2 \mathrm{ka}$, and of the regrowth layer $28 \pm 2 \mathrm{ka}$. Thus, the youngest observable movement, took place between 32 and $28 \mathrm{ka}$.

\section{St. Beatus Cave}

In nearby St. Beatus Cave, four soda straws were sampled for dating. Three of these soda straws, taken at the same location, were broken and lying on the floor of the passage. BB1 was cemented to the floor, BB2 was free, and BB3 was lying on top of BB2, so a relative chronology could be established. One was still actively growing. Particularly long soda straws are very fragile and may be easily broken by an earthquake (Lacave et al., 2004). If they can be dated with normal means, even with their small mass, they may give an interesting method for investigating past earthquakes. However, the first three broken soda straws (BB1-3), albeit datable, have shown an inversion of ages. This might be because they are of different age, with the younger ones breaking before the older ones, or it might be because of leakage of uranium. The samples 

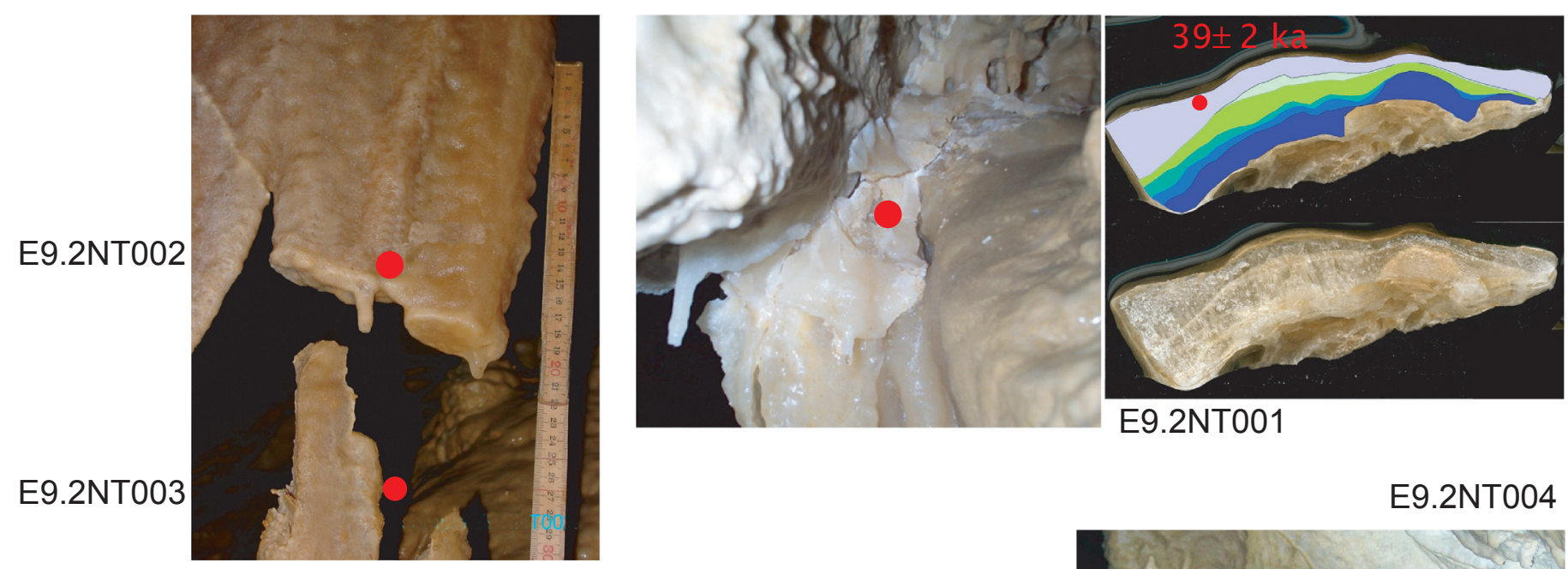

E9.2NT001

E9.2NT004
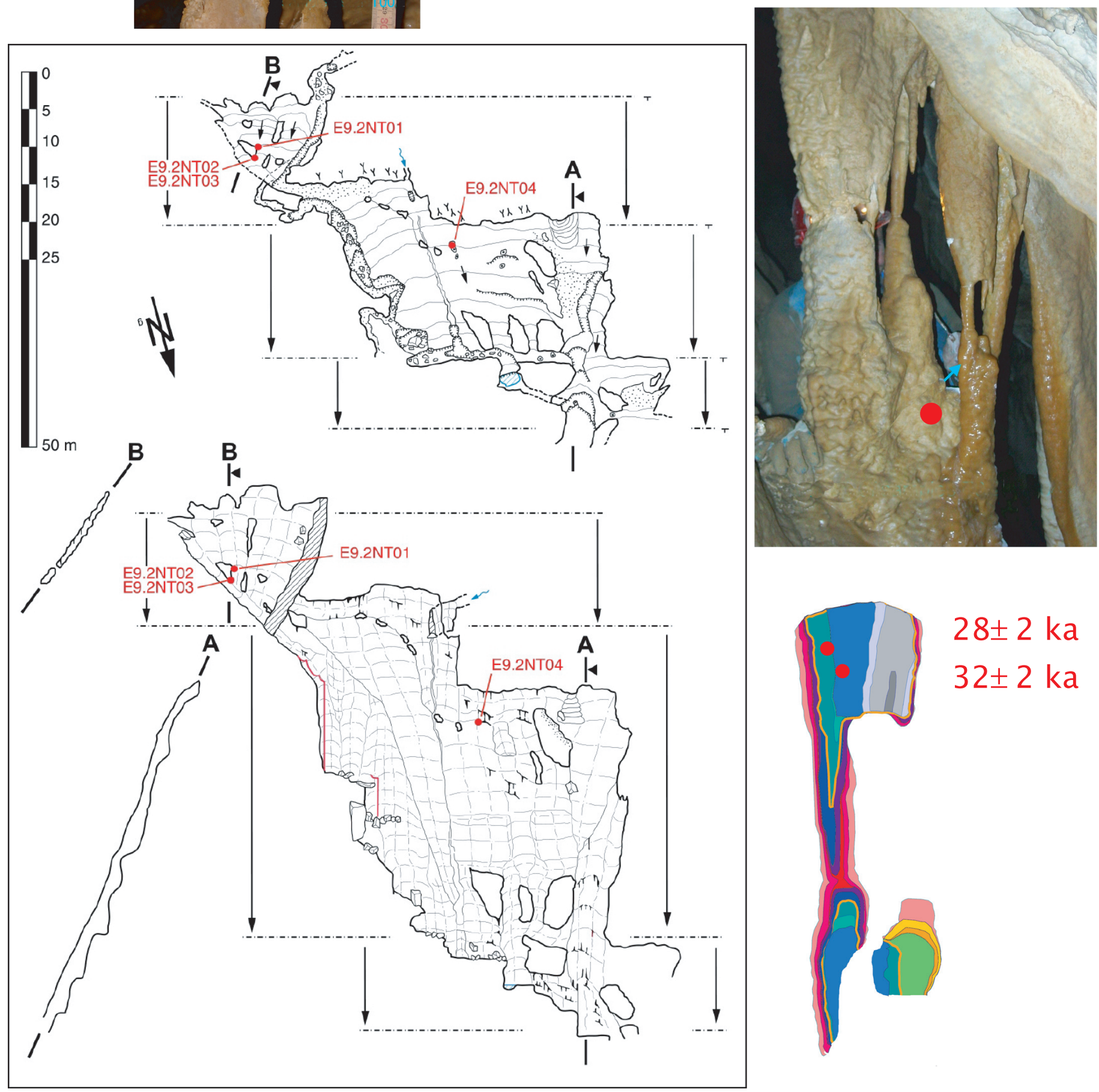

$28 \pm 2 \mathrm{ka}$

$32 \pm 2 \mathrm{ka}$

Fig. 16. Location of samples in the cave E9.2 (Siebenhengste) as well as pictures of the samples. The vertical arrows on the map indicate identical places in map view (above) and longitudinal section (below). 
are very well suited for dating (Table 1), so it seems that the method should work. To investigate if the age inversion was due to leaching of uranium within the sample, a fourth sample, actively growing, was taken to investigate the feasibility of age dating recent speleothems. Unfortunately, the uranium content of the sample was very low and the investigation was abandoned. It is, however, an interesting topic that should be pursued in the future.

\section{Summary for the Siebenhengste-Hohgant region}

The most recent fault activity is dated between 28 and 32 ky BP (Table 1). A major compressive event with some $30 \mathrm{~cm}$ of displacement (reverse) is dated between 138 and $145 \mathrm{ky}$. An extensional displacement of minor importance $(4-6 \mathrm{~cm})$ is dated between 145 and $185 \mathrm{ky}$. These observations and dates clearly indicate fault activities during the last $200 \mathrm{ky}$, most likely by creep in a slow and regular manner and not by co-seismic displacements. Complementary dating of damaged speleothems will significantly improve our knowledge about the recent tectonic history of this region.

\section{SUMMARY}

Caves are natural archives that may preserve sediments and surface expressions of tectonic displacements and paleo-earthquakes for an extended period of time (Becker et al., 2006; Gilli, 2005). Movements of fractures and faults can be recognized by displaced and/or broken or shifted speleothems, which can be dated. Dieboldslöchli cave near Basle is an example which presents evidence for active displacement of a fault and speleothem damage due to the 1356 Basle earthquake (Lemeille et al., 1999). Other caves nearby show rock falls which might indicate seismic events (Becker et al., 2006); however, the ages obtained from speleothems and organic matter in sediments covered by rockfall blocks in caves indicate a Pleistocene to Holocene age that cannot be related to known historic earthquakes. In Milandre Cave, the ages of dated speleothems suspected to have been influenced by active displacements or paleo-earthquakes are between $3.8 \mathrm{ka}$ up to $60 \mathrm{ka}$. Although Milandre Cave could have been affected by the 1356 Basle earthquake, no proof could be found so far.

In the area of Melchsee-Frutt, all the dated samples extend from $75 \mathrm{ka}$ to above the limit of U/Th dating. An interpretation of the fault system in that area concluded that most of the observed damages and displacements are related to gravitational slip of the rock mass towards the valley. Also in the Siebenhengste region, very young ruptures and displacements could not be detected; the youngest one is between 32 and $28 \mathrm{ka}$.

Most of the ages obtained in this study are too old to be compared with the historical earthquake record. It thus remains uncertain whether the observed displacements were triggered by earthquakes or aseismic creep along faults.

In general the proof that speleothem dam ages were caused by earthquakes is very difficult to find, because there are many other possible mechanisms leading to cave damage (Becker et al., 2006; Gilli, 2004, 2005). Detailed studies considering all paleoenvironmental records in caves might establish a relative chronology of all these events. Evidence for earthquakes could possibly be filtered out of such a detailed data base. However, many more observations and date determinations are necessary to reach this state of knowledge.

\section{ACKNOWLEDGEMENTS}

Urs Eichenberger and Pierre-Yves Jeannin are thanked for their support to collect the field data and inspiring discussions concerning neotectonic deformations in caves. We gratefully acknowledge Augusto Mangini, Heidelberger Akademie der Wissenschaften, for U-Th- and ESR-measurements of samples from Milandre, Bettenhöhle and Rundwandhöhle. Art Palmer kindly corrected the English. Three reviews helped to improve the publication. The project has been partly funded by the Swiss National Science Foundation in the frame of the Paleoseis project at ETH Zurich, Geophysical Institute, Prof. Dr. D. Gardini.

\section{REFERENCES}

Becker A., 2005 - Radiokohlenstoff-Altersdatierungen an Sedimenten der Glitzersteinhöhle. D'Höhleperle: 28-33.

Becker A. \& Davenport C.A., 2003 - Rockfalls triggered by the $A D 1356$ Basle earthquake. Terra Nova 15(4): 258-264.

http://dx.doi.org/10.1046/j.1365-3121.2003.00496.x

Becker A., Davenport C.A., Eichenberger U., Gilli E., Jeannin P.Y. \& Lacave C., 2006 - Speleoseismology: a critical perspective. Journal of Seismology, 10 (3): 371-388. http://dx.doi.org/10.1007/s10950-006-9017-Z

Bitterli T., 1996 - Höhlen der Region Basel-Laufen. Speläologisches Inventar der Schweiz, 3: 1-328.

BitterliT.\&JeanninP.-Y., 1997-Entwicklungsgeschichte der Höhlen im Gebiet Hohgant - Sieben Hengste Thunersee (Berner Oberland, Schweiz). Proceed. $12^{\text {th }}$ Int. Congress of Speleology, 1: 349-354.

Bitterli-Brunner P. \& Fischer H., 1988 - Erläuterungen zum geologischen Atlas der Schweiz 1:25000, Blatt 1067 Arlesheim. Landeshydrologie und -geologie, $66 \mathrm{p}$.

Bitterli-Brunner P., Fischer H. \& Herzog P., 1984 Geologischer Atlas der Schweiz 1:25000, Blatt 1067 Arlesheim. Landeshydrologie und -geologie, 1 map.

Eikenberg J., Vezzu G., Zumsteg I., Bajo S., Rüthi M. \& Wyssling G., 2001 - Precise two chronometer dating of Pleistocene Travertine: the ${ }^{230} \mathrm{Th} /{ }^{234} \mathrm{U}$ and ${ }^{226} \mathrm{Ra}_{e x} /{ }^{226} \mathrm{Ra}(\mathrm{O})$ approach. Quaternary Science Reviews, 20: 1935-1953. http://dx.doi.org/10.1016/S0277-3791(01)00020-8

Eikenberg J., 2002 - Radium isotope systematics in nature: applications in geochronology and hydrogeochemistry. Habilitation Thesis, PSI report 02-24, ISSN 1019-0643, Paul Scherrer Institute, CH-5232 Villigen, Switzerland, 193 p. 
Fäh D., Giardini D., Bay F., Bernardi F., Braunmiller J., Deichmann N., Furrer M., Gantner L., Gisler M., Isenegger D., Jimenez M.J., Kästli P., Koglin R., Masciadri V., Rutz M., Scheidegger C., Schibler R., Schorlemmer D., Schwarz-Zanetti G., Steimen S., Sellami S., Wiemer S. \& Wössner J., 2003 Earthquake catalogue of Switzerland (ECOS) and the Related Macroseismic Database. Eclogae geologicae Helvetiae, 96: 219-236.

Fäh D., Gisler M., Jaggi B., Kästli P., Lutz T., Masciadri V., Matt C., Mayer-Rosa D., Rippmann D., SchwarzZanetti G., Tauber J. \& Wenk T., 2009 - The 1356 Basel earthquake: an interdisciplinary revision. Geophysical Journal International, 178: 351-373. http://dx.doi.org/10.1111/j.1365-246X.2009.04130.x

Ferry M., Meghraoui M., Delouis B. \& Giardini D., 2005 - Evidence for Holocene paleoseismicity along the Basel-Reinach Active Normal Fault (Switzerland): A Seismic Source for the 1356 Earthquake in the Upper Rhine Graben. Geophysical Journal International 160: 554-572. http://dx.doi.org/10.1111/j.1365-246X.2005.02404.x

Forti P. \& Postpischl D., 1980 - The hypothesis of the induced activity of the faults as a result of a statistical analysis of stalagmites. Proc. Europ. Reg. Speleol. Conf. Sofia 352 P.F.G./C.N.R: 3439.

Forti P. \& Postpischl D., 1984 - Seismotectonic and paleoseismic analyses using karst sediments. Marine Geology, 55: 145-161. http://dx.doi.org/10.1016/0025-3227(84)90138-5

Gilli E., 1986 - Néotectonique dans les massifs karstiques. Un exemple dans les Préalpes de Nice: la grotte des Deux Gourdes. Karstologia, 8: 50-52.

Gilli E., 2004 - Glacial causes of damage in caves and difficulties to use speleothems as seismic or neotectonic indicators. Geodinamica Acta, 17 (3): 229-240.

http://dx.doi.org/10.3166/ga.17.229-240

Gilli E., 2005 - Review of the use of natural cave speleothems as paleoseismic or neotectonic indicators. Comptes Rendus Geosciences, 337: 1208-1215. http://dx.doi.org/10.1016/j.crte.2005.05.008

Gilli E., Levret A., Sollogoub P. \& Delange P., 1999 Research on the February 18, 1996 earthquake in the caves of Saint-Paul-de-Fenouillet area, (eastern Pyrenees, France). Geodinamica Acta, 12(3-4): 143-158. http://dx.doi.org/10.1016/S0985-3111(00)88654-4

Gubler T. \& Trüssel M. 1997 - Beschreibung einer Höhle auf Melchsee-Frutt, Kerns OW, mit neotektonischen Verschiebungen. Naturf. Gesell. Ob- u. Nidwalden, 1: 20-35.

Haller J. 1949 - Die Glitzersteinhöhle. Leben und Umwelt, 6: 169-177.

Häuselmann Ph, Granger D.E., Jeannin P.-Y. \& Lauritzen S.E., 2007 - Abrupt glacial valley incision at $0.8 \mathrm{Ma}$ dated from cave deposits in Switzerland. Geology, 35(2): 143-146.

http://dx.doi.org/10.1130/G23094A
Häuselmann Ph., Lauritzen S.-E., Jeannin P.-Y. \& Monbaron M., 2008 - Glacier advances during the last $400 \mathrm{ka}$ as evidenced in St. Beatus Cave (BE, Switzerland). Quaternary International, 189: 173-189.

http://dx.doi.org/10.1016/j.quaint.2008.04.011

Ivanovich M. \& Harmon R.S., 1992 - Uranium series disequilibrium. Oxford Science Publisher. Claredon Press, Oxford, 910 p.

Jeannin P.-Y., 1989 - Etude géologique de la région Burst / Sieben-Hengste. Apports de l'étude des cavernes à la connaissance structurale et la mise en évidence de phases tectoniques quaternaires. Travail de diplôme de géologie, Université de Neuchâtel, 122 p.

Jeannin P.-Y., 1990 - Néotectonique dans le karst du nord du Lac de Thoune (Suisse). Karstologia, 15: 41-54.

Jeannin P.-Y., Bitterli T. \& Häuselmann Ph., 2000 - Genesis of a large cave system: the case study of the North of Lake Thun system (Canton Bern, Switzerland). In: Klimchouk A.B., Ford D.C., Palmer A.N. \& Dreybrodt W. (Eds.), Speleogenesis, Evolution of Karst Aquifers. National Speleological Society: Huntsville: 338-347.

Jeannin P.-Y. \& Häuselmann Ph., 2005 - Siebenhengste Cave System, Switzerland. In: Culver D. C. \& White W. B. (Eds.), Encyclopedia of caves. Elsevier Academic Press: New York: 500-509.

Kagan E.J., Agnon A., Bar-Matthews M. \& Ayalon A., 2005 - Dating large infrequent earthquakes by damaged cave deposits. Geology, 33(4): 261-264. http://dx.doi.org/10.1130/G21193.1

Lacave C., Koller M.G. \& Egozcue J.J., 2004 - What can be concluded about seismic history from broken and unbroken speleothems? Journal of Earthquake Engineering, 8(3), 431-455.

http://dx.doi.org/10.1142/S1363246904001493

Lemeille F., Cushing M., Carbon D., Grellet B., Bitterli T., Flehoc C. \& Innocent C., 1999 - Coseismic ruptures and deformations recorded by speleothems in the epicentral zone of the Basel earthquake. Geodinamica Acta, 12(3-4): 179-191. http://dx.doi.org/10.1016/S0985-3111(00)88657-X

Lignier V. \& Desmet V., 2002 - Les archives sédimentaires quaternaires de la grotte sous les Sangles. Karstologia 39 (1): 27-46.

Mayer-Rosa D. \& Cadiot B., 1979 - A Review of the 1356 Basel Earthquake: Basic Data. Tectonophysics, 53: 325-333.

Mayer-Rosa D. \& Schwarz-Zanetti G., 2004 - On historical earthquakes in Switzerland: summary of compilations and investigations. Annals of Geophysics, 47 (2/3): 621-630.

Meghraoui M., Delouis B., Ferry M., Giardini D., Huggenberger P., Spottke I. \& Granet M., 2001 Active normal faulting in the Upper Rhine Graben and paleoseismic identification of the $1356 \mathrm{Basel}$ earthquake. Science, 293: 2070-2073. http://dx.doi.org/10.1126/science.1010618 
Schwarz-Zanetti G., Deichmann N., Fäh D., Giardini D., Jimenez M.J., Masciadri V., Schibler R. \& Schnellmann M., 2003 - The earthquake in Unterwalden on September 18, 1601 - A historic-critical macroseismic evaluation. Eclogae geologicae Helvetiae, 96: 441-450.

Tepley F.J., Lundstrom C.C., Gill J.B. \& Williams R.W., 2006 - U-Th-Ra disequilibria and the time scale of fluid transfer and andesite differentiation at Arenal volcano, Costa Rica. Journal of Volcanological and Geothermal Research, 157: 147-165.

http://dx.doi.org/10.1016/j.jvolgeores.2006.03.038
Weber E., 2004 - Etude des mouvements récents dans les karsts du Melchsee-Frutt (OW). Apport de la modélisation $3 D$ et comparaison avec la grotte de Milandre (JU) et le réseau des Siebenhengste $(B E)$. Travail de diplôme de géologie, Université de Neuchâtel, 167 p. 